\title{
Biological Activities of Schiff Bases and Their Complexes: A Review of Recent Works
}

\author{
Wail Al Zoubi \\ Department of Chemistry, Faculty of Science, University of Damascus, Damascus, Syria \\ Email: wwailalzoubi@yahoo.com, Wailzoubi@yahoo.com
}

Received August 26, 2013; revised October 1, 2013; accepted October 15, 2013

Copyright (C) 2013 Wail Al Zoubi. This is an open access article distributed under the Creative Commons Attribution License, which permits unrestricted use, distribution, and reproduction in any medium, provided the original work is properly cited.

\begin{abstract}
Schiff bases are the most widely used organic compounds. They have been shown to exhibit a broad range of biological activities, including antifungal, antibacterial, antimalarial, antiproliferative, anti-inflammatory, antiviral, and antipyretic properties. This review summarizes the synthesis and biological activities of Schiff bases and their complexes.
\end{abstract}

Keywords: Schiff Bases; Metal Complexes; Antibacterial; Biological Activities

\section{Introduction}

Schiff base compounds and their metal complexes have been extensively investigated due to their wide range of applications including catalysts $[1,2]$, medicine $[3,4]$ crystal engineering [5], anti-corrosion agent [6,7]. Schiff bases are studied widely due to their synthetic flexibility, selectivity and sensitivity towards the central metal atom; structural similarities with natural biological compounds and also due to presence of azomethine group(-N=CH-) which imports in elucidating the mechanism of transformation and racemization reaction biologically $[8,9]$. Schiff bases having chelation with oxygen, nitrogen etc. donors and their complexes have been used as drugs and reported to possess a wide variety of biological activities against bacteria, fungi, and certain type of tumors and also, they have many biochemical, clinical and pharmacological properties [10-14]. Imine or azomethine groups are present in various natural, naturally derived and nonnatural compounds (Figure 1). The imine group present in such compounds has been shown to be critical to their biological activities [15-17].

This review concentrates on the synthesis and biologi-<smiles>[R3]N=C([R])[R]</smiles>

$\mathbf{R}_{1}, \mathbf{R}_{\mathbf{2}}$ and / or $\mathbf{R}_{3}=$ alkyl or aryl

Figure 1. General Structure of a Schiff base. cal activity of Schiff bases and their complexes.

\section{Biological Activities of Schiff Bases}

Schiff bases are generally bi- or tridentate ligands capable of forming very stable complexes with transition metals. In organic synthesis, Schiff base reactions are useful in making carbon-nitrogen bonds.

Complexes of $\mathrm{Co}(\mathrm{II})$ and $\mathrm{Ni}(\mathrm{II})$ with new Schiff bases (Scheme 1) derived from 4-amino-5-sulfanyl-1.2.4-triazoles and glyoxal, biacetyl or benzil have been prepared. All have the stoichiometry $\mathrm{ML}\left(\mathrm{H}_{2} \mathrm{O}\right)_{2}$, with L coordination via the two imine nitrogens and two thiolato sulfurs in an overall octahedral geometry. Some of the complexes were screened for their antibacterial and antifungal activity, and one representative $\mathrm{Co}$ (II) complex was evaluated for oxytocic. Furthermore, complex(c) (R; Me, $\mathrm{R}^{1}$; H) was found to inhibit the oxytocic activity of oxytocin on isolated rat uterus (Table 1) [18].

Tumer and coworkers have been prepared and characterized mixed ligand complexes (Scheme 2) of copper(II)<smiles>[R]C(=N/n1c([R])nnc1S)/C([R])=N/n1c(S)nnc1S</smiles>

Scheme 1. Complexes of Co (II) and Ni(II) with new Schiff baese. 
Table 1. Data showing the oxytocic activity of cobalt(II) complex(c).

\begin{tabular}{ccc}
\hline $\begin{array}{c}\text { Vol. of test solution } \\
\text { added }\left(\mathrm{cm}^{3}\right)\end{array}$ & $\begin{array}{c}\text { Peak } \\
\text { Height }(\mathrm{cm})\end{array}$ & $\begin{array}{c}\text { Oxytocic } \\
\text { activity }(\%)\end{array}$ \\
\hline 0.1 (Std. oxytocic) & 3.1 & 88.57 \\
0.2 (Std. oxytocic) & 3.5 & 100.00 \\
0.3 (Std. oxytocic) & 3.5 & 100.00 \\
& & (Saturation pt) \\
$\left(\mathrm{C}_{8} \mathrm{H}_{8} \mathrm{~N}_{8} \mathrm{~S}_{2}\right)$ Co.2 $\mathrm{H}_{2} \mathrm{O}$ & 3.4 & 97.15 \\
$0.3 \mathrm{~cm}^{3} \mathrm{Std}$. oxytocic & & (2.85 Inhibition) \\
\hline
\end{tabular}

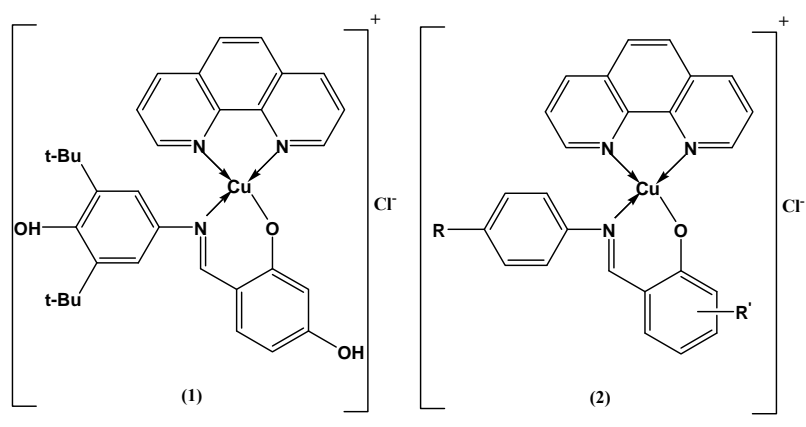

Scheme 2. Suggested structure for the mononuclear complexes of the ligands $\mathrm{HL}_{3}(1), \mathrm{HL}_{1}-\mathrm{HL}_{4}$ and $\mathrm{HL}_{1}, \mathrm{HL}_{4}(2)$.

with 1.10-phenanthroline and Schiff bases. Some of the free ligands and their complexes were found to be highly active against both the Bacillus megaterium and Candida tropicalis. However, the metal complexes were active compared with corresponding ligands as regards to antimicrobial activity of the molecule [19].

Two tridentate Schiff bases (Scheme 3) having ONS and NNS donor sequences were prepared by condensing S-benzyldithiocarbazate $\left(\mathrm{NH}_{2} \mathrm{NHCSSCH}_{2} \mathrm{Ph}\right)$ (SBDTC) with pyridine-2-carboxaldehyde and salicylaldehyde, respectively. Complexes of theses ligands with $\mathrm{Ni}(\mathrm{II})$, $\mathrm{Zn}(\mathrm{II}), \mathrm{Cr}(\mathrm{III}), \mathrm{Co}(\mathrm{II}), \mathrm{Cu}(\mathrm{II})$, and $\mathrm{Sn}(\mathrm{II})$ were studied and Characterized by elemental analyses and various physico-chemical techniques. The ONS Schiff base was moderately active against leukemia, while its zinc, antimony and cobalt complexes were strongly active against leukemic cells with $D C_{50}=0.35-5.00$ [20].

Paola et al have reported the synthesis, characterization and evaluation as antibacterial and antifungal agents of a series of hydrazones (Scheme 4) of 1.2-benzisothiazole hydrazides as well as their cyclic and acyclic 1.2benzisothiazole parent hydrazides. All of the 2-amino1.2-benzisothiazol-3(2H)-one derivatives, belonging to series I and IV, showed a good antibacterial activity against Gram positive bacteria. Most of them were active against yeasts too. Compounds 1 and 4, together with II, proved to be the most effective compounds [21].
Sevim and coworkers have reported the synthesis and evaluation a series of hydrazide hydrazones and 1.3.4oxadiazolines of 4-fluorobenzoic and hydrazide (Scheme 5) as potential antimicrobial agents and have tested for their antibacterial and antifungal activities against Staphylococcus aureus, Escherichia coli, Pseudomonas aeruginosa and Candida albicans. From these compounds, 4-fluorobenzoic acid [(5-nitro-2-furanyl) methylene] hydrazide(1a) showed equal activity with ceftriaxone against $S$. aureus [22].

Two new Schiff base ligands (Scheme 6) containing 2,4-disubstituted thiazoles and cyclobutane rings, 4-(1methyl-1-phenylcyclobutane-3-yl)-2-(2-hydroxy-3-

methoxy benzylidene hydrazino)thiazole $\left(\mathrm{L}_{1} \mathrm{H}\right), 4-(1-$ methyl-1-p-xylylcyclobutane-3-yl)-2-(2-hydroxy-3-meth oxybenzylidenehydrazino)thiazole $\left(\mathrm{L}_{2} \mathrm{H}\right)$ and their mononuclear complexes with a 1:2 metal-ligand ratio have been prepared from acetate salts of $\mathrm{Co}(\mathrm{II}), \mathrm{Cu}(\mathrm{II})$, $\mathrm{Ni}(\mathrm{II})$ and $\mathrm{Zn}(\mathrm{II})$ in EtOH. Antimicrobial activities of the ligands and their complexes have been tested against six different microorganisms; three are yeast and three are bacteria [23].

Natarajan and coworkers have reported the synthesis neutral tetradentate chelate complexes of $\mathrm{Cu}(\mathrm{II}), \mathrm{Ni}(\mathrm{II})$, $\mathrm{Co}(\mathrm{II}), \mathrm{Mn}(\mathrm{II}), \mathrm{Zn}(\mathrm{II})$ and $\mathrm{VO}(\mathrm{II})$ in EtOH using Schiff bases (Scheme 7) derived from acetoacetanilido-4-aminoantipyrine and 2-aminophenol/2-aminothiophenol. Microanalytical data, magnetic susceptibility, IR., UV-vis., ${ }^{1} \mathrm{H}-\mathrm{NMR}$. and ESR spectral techniques were used to confirm the structures of the chelates. The in vitro antimicrobial activity of the investigated compounds was tested against the microorganisms such as Salmonella typhi, Staphylococcus aureus, Klebsiella pneumoniae, Bacillus subtilis, Shigella flexneri, Pseudomonas aeruginosa, Aspergillus niger and Rhizoctonia bataicola. Most of the metal chelates have higher antimicrobial activity than the free ligands [24].

Daniel et al have reported the synthesis chiral Schiff base of ruthenium(III) of the type $\left[\mathrm{RuX}\left(\mathrm{LL}^{\prime}\right)\left(\mathrm{Eph}_{3}\right)\right](\mathrm{X}=$ $\mathrm{Cl}$ or $\mathrm{Br} ; \mathrm{LL}^{\prime}=$ chiral Schiff base; $\mathrm{E}=\mathrm{P}$ or As) (Scheme 8) by the reactions of $\left[\mathrm{RuX}_{3}\left(\mathrm{Eph}_{3}\right)_{3}\right]$ or $\left[\mathrm{RuBr}_{3}\left(\mathrm{PPh}_{3}\right)_{2}(\mathrm{MeOH})\right]$ with appropriate Schiff bases having the donor groups $(\mathrm{O}, \mathrm{N})$ viz., bis[3(1-naphthyl) salicylidenecy cyclohexanediimine $]\left(\mathrm{L}_{1}\right)$ or bis[(1-naphthyl) salicyli denepropylenediimine] $\left(\mathrm{L}_{2}\right)$ or bis[3(1-naphthyl) salicylidene diphenyldiimine $]\left(\mathrm{L}_{3}\right)$ in 1:1 molar ratio. The catalytic and antibacterial activities have also been carried out for these new complexes [25-29].

The synthesis and vitro antifungal activity of some Schiff bases (Scheme 9) and their Sn(IV) complexes has been tested against plant pathogenic fungi and it is found that they possess excellent fungicidal activity [30].

The vitro antibacterial antifungal activities of five different amino acid Schiff bases (Scheme 10) derived from 
the reaction of 2-hydroxy-1-naphthaldehyde with glycine, L-alanine L-phenylalanine, L-histidine, L-tryptophane and the manganese(III) complexes of these bases were studied. In vitro activities against some Gram-positive (Staphylococcus aureus and Bacillus polymyxa) and Gram-negative (Escherichia coli) bacteria and the fungus Candida albicans were determined. The antimicrobial activities tended to decrease with the increasing size of the amino acid residues [31].

\begin{tabular}{|c|c|c|c|c|c|}
\hline \multicolumn{2}{|c|}{ Schiff bases } & \multicolumn{2}{|c|}{ Complexes } & \multicolumn{2}{|c|}{$\mathrm{R}$} \\
\hline 1 & $\mathrm{H}_{2} \mathrm{~L}^{1}$ & 6 & $\mathrm{Na}\left[\mathrm{MnL}_{2}{ }^{1}\right]$ & $\mathrm{H}$ & (Gly) \\
\hline 2 & $\mathrm{H}_{2} \mathrm{~L}^{2}$ & 7 & $\mathrm{Na}\left[\mathrm{MnL}_{2}^{2}\right]$ & $\mathrm{CH}_{3}$ & (Ala) \\
\hline 3 & $\mathrm{H}_{2} \mathrm{~L}^{3}$ & 8 & $\mathrm{Na}\left[\mathrm{MnL}_{2}{ }^{3}\right]$ & & (Phe) \\
\hline 4 & $\mathrm{H}_{2} \mathrm{~L}^{4}$ & 9 & $\mathrm{Na}\left[\mathrm{MnL}_{2}{ }^{4}\right]$ & & (His) \\
\hline 5 & $\mathrm{H}_{2} \mathrm{~L}^{5}$ & 10 & $\mathrm{Na}\left[\mathrm{MnL}_{2}^{5}\right]$ & & (Trp) \\
\hline
\end{tabular}

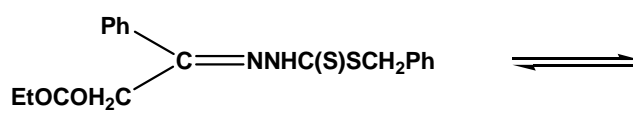

(Thione form)

(1a)

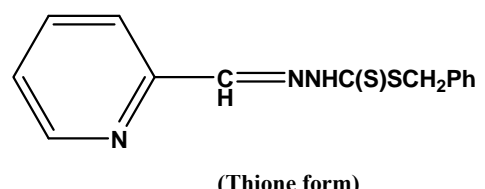

(2a)
Two small sets of aromatic Schiff bases and 2,3-diiaryl-1,3-thiazolidin-4-one (Scheme 11) derivatives have been prepared and tested for anti-inflammatory and antinociceptive activities. The thiazolidinone derivatives have been obtained from the azomethines through the addition of $\alpha$-mercaptoacetic acid. Both types of compounds displayed good level of activity against carrageenan induced edema in rat hind paw, while only moderate activity was observed in the writhing test in mice [32].

Esin and coworkers have reported the synthesis two new Schiff bases ligands (Scheme 12) containing $-\mathrm{SiOCH}_{3}$ or $-\mathrm{SiOCH}_{2} \mathrm{CH}_{3}$ groups, 4-\{[(3-trimethoxysilanepropyl) imino $]$ methyl $\}$ benzene-1.3-diol(1) Hmsb and 4-\{[(3triethoxysilanepropyl)imino]methyl benzene-1.3-diol (5) Hesb by the reaction of 2.4-dihydroxybenzaldehyde with 3 -aminopropyltrimethyoxysilane and 3-amninopropyltriethoxysilane. Six new transition metal $[\mathrm{Cu}(\mathrm{II}), \mathrm{Ni}(\mathrm{II})$ and $\mathrm{Co}(\mathrm{II})]$ complexes of these Schiff base ligands were prepared. The analytical data shows that the metal-toliagnd ratio in the Schiff base complexes contains silane in 1:2. In addition the antimicrobial activity of (1) Hmsb and (5) Hesb Schiff ligands, and their $\left[\mathrm{M}(\mathrm{msb})_{2}\right]$ and $\left[\mathrm{M}(\mathrm{esb})_{2}\right]$ type coordination compounds, were investi-

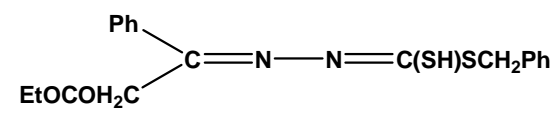

(Thiol form)

(1b)

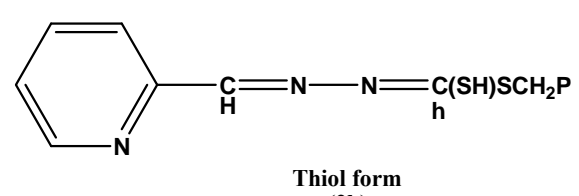

(2b)

Scheme 3. Synthesis of Tridentate Schiff bases having ONS and NNS.

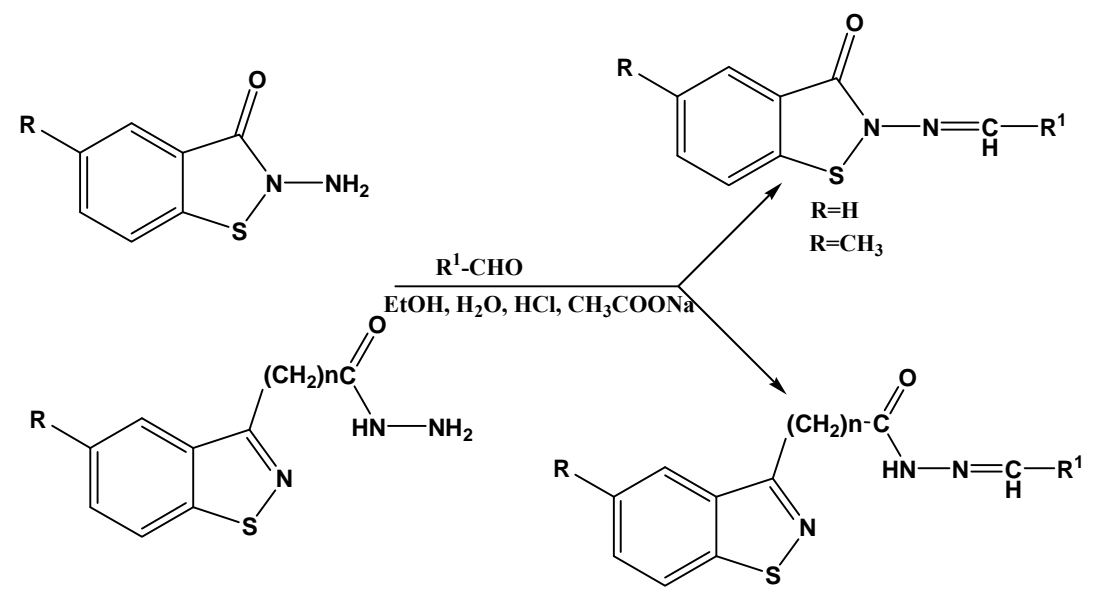

Scheme 4. General Scheme for synthesis of 1.2-benziosthiazole hydrazones. 


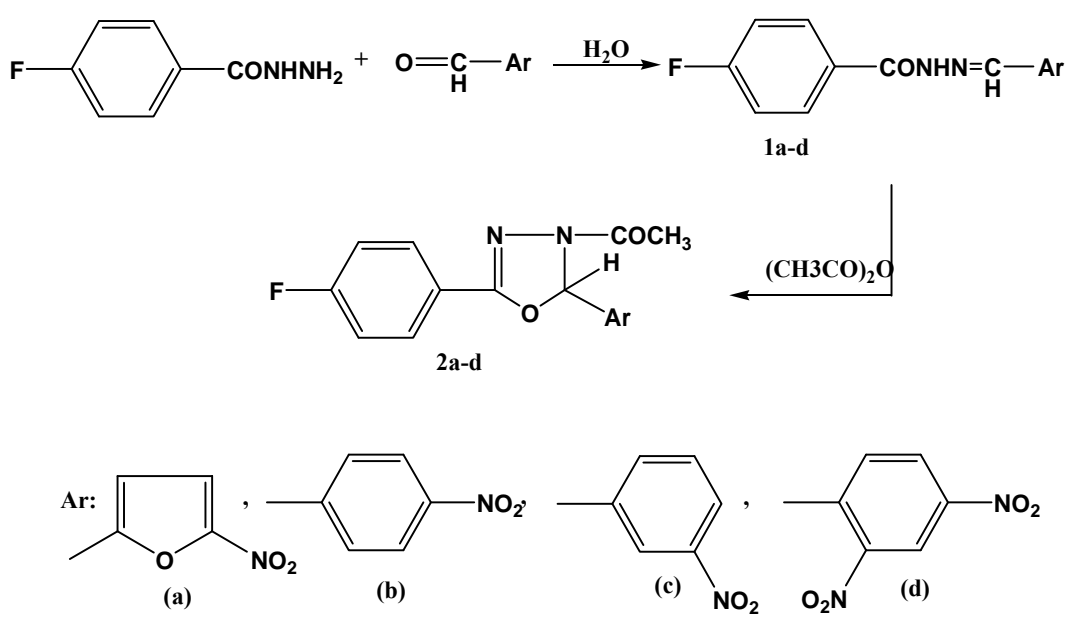

Scheme 5. Scheme of Synthesis a series of hydrazide hydrazones.<smiles>COc1cccc(/C=N/NC(N)=S)c1O</smiles>

(1)

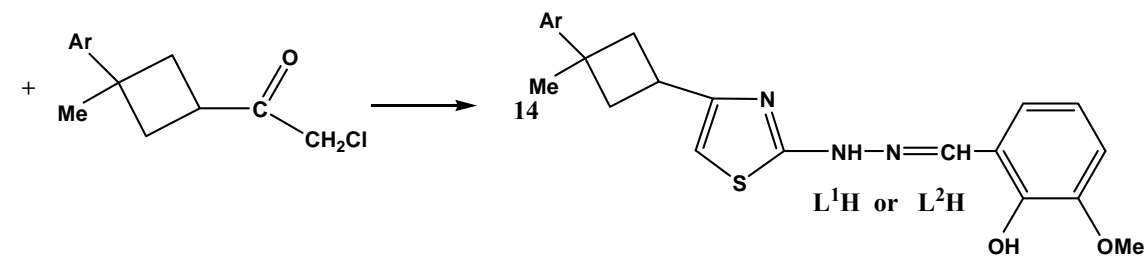

Scheme 6. Synthesis of Schiff bases ligands.

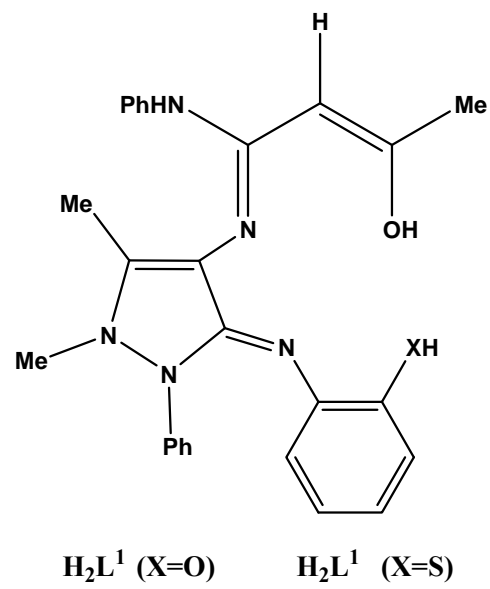

Scheme 7. Synthesis Schiff bases derived from acetoacetanilido-4-aminoantipyrine and 2-aminophenol/2-aminothiophenol.

gated [33-35].

Raman and coworkers have reported the synthesis of four copper (II) complexes (Scheme 13) using macrocyclic ligands. The macrocyclic ligands have been synthesized by the condensation reaction of diethyl phthalate with Schiff bases derived from o-phenylene diamine and
Knoevenagel condensed $\beta$-ketoanilides (obtained by the condensation of acetoacetanilide and substituted benzaldehydes). The in vitro antifungal activities of the compounds were tested against fungi such as Aspergillus niger, Rhizopus stolonifer, Aspergillus flavus, Rhizoctonia bataicola and Candida albicans. All the synthesized copper complexes showed stronger antifungal activities than free ligands [36].

Hitesh et al have reported the synthesis mixed-ligand complexes (Scheme 14) of $\mathrm{Mn}(\mathrm{II}), \mathrm{Co}(\mathrm{II}), \mathrm{Ni}(\mathrm{II}), \mathrm{Cu}(\mathrm{II})$, $\mathrm{Zn}(\mathrm{II})$, and $\mathrm{Cd}(\mathrm{II})$ with biologically active Schiff bases, viz. potassium salt of $o$-hydroxyacetophenoneglycine [KHL] and bis(benzylidene) ethylenediamine $\left[\mathrm{A}^{1}\right]$ or thiophene-o-carboxaldene-p-toluidine $\left[\mathrm{A}^{2}\right]$. The mixedligand complexes show higher antifungal activity as compared to the free ligands, metal salts, and the control (dimethylsulfoxide) but moderate activity as compared to the standard fungicides (bavistin and emcarb) [37].

A relationship between antimicrobial activities and the formation constants of amino acid-Schiff bases (Scheme 15) and their $\mathrm{Cu}(\mathrm{II})$ and $\mathrm{Ni}(\mathrm{II})$ complexes was studied. For this purpose, a series of Schiff bases were prepared from DL-amino acids (DL-glycine, DL-alanine) and haloaldehydes (5-chloro-2-hydroxybenzaldehyde, 5- 
<smiles>[R2]C(/N=C/c1cccc(-c2cccc3ccccc23)c1O)[C@@H]([R2])N=Cc1cccc(-c2cccc3ccccc23)c1O</smiles>

$\left[\operatorname{RuX}_{3}\left(\mathrm{EPh}_{3}\right)_{3}\right]$ or $\left[\operatorname{RuBr}_{3}\left(\mathrm{PPh}_{3}\right)_{2}(\mathrm{MeOH})\right]$
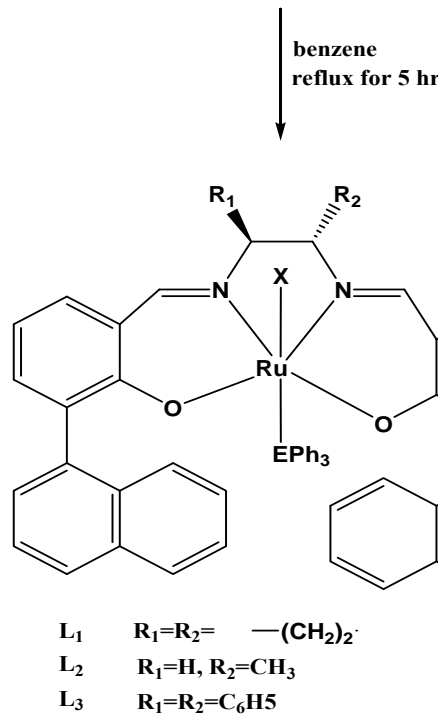

Scheme 8. Scheme synthesis of the ruthenium (III) complexes.
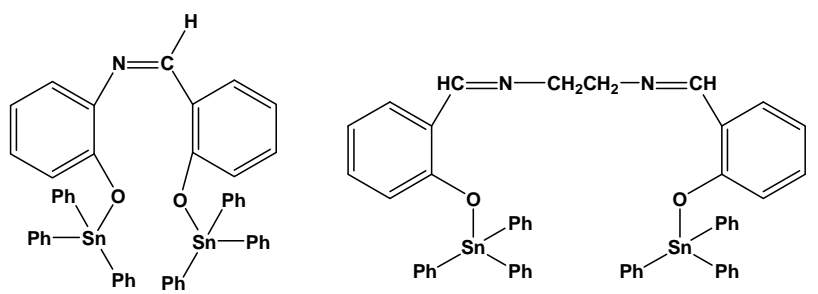

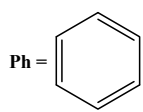

Scheme 9. Proposed structure for compounds.<smiles>[R]C(/N=C/c1c(O)ccc2ccccc12)C(=O)O</smiles>

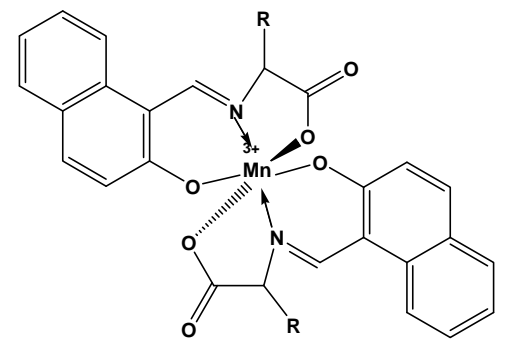

Scheme 10. Structure of the Schiff bases and $\mathrm{Mn}^{3+}$ complexes investigated. bromo-2-hydroxybenzaldehyde). The complexes were found to have general compositions $\left[\mathrm{ML}\left(\mathrm{H}_{2} \mathrm{O}\right)\right]$. The protonation constants of the Schiff bases and stability constants of the complexes were determined potentiometrically in a dioxane-water $(1: 1)$ solution at $25^{\circ} \mathrm{C}$ and $0.1 \mathrm{M} \mathrm{KCl}$ ionic strength. Antimicrobial activities of the Schiff bases and their complexes were estimated for six bacteria, such as Bacillus cereus RSKK 863, Staphylococcus aureus ATCC 259231, Micrococcus luteus NRLL B-4375, Escherichia coli ATCC 11230, Aeromonas hydrophila 106, Pseudomonas aeroginosa ATCC 29212, and the yeast Candida albicans ATCC 10239. The role of halogen substitution on the ligands, effect of the metal ion, and stabilities of the complexes are discussed on antimicrobial activities [38].

Dharmarajan and coworkers have reported the synthesis and evaluation various diclofenac acid hydrazones and amides (Scheme 16) for in vitro and in vivo antimycobacterial activities against Mycobacterium tuberculosis [39].

Schiff base tetraazamacrocyclic ligand (Scheme 17), L $\left(\mathrm{C}_{40} \mathrm{H}_{28} \mathrm{~N}_{4}\right)$ and its complexes of types, [MLX $\left.{ }_{2}\right]$ and $[\mathrm{CuL}] \mathrm{X}_{2}\left(\mathrm{M}=\mathrm{Co}(\mathrm{II}), \mathrm{Ni}(\mathrm{II}), \mathrm{Zn}(\mathrm{II}) ; \mathrm{X}=\mathrm{Cl}^{-}, \mathrm{NO}_{3}^{-}\right)$were synthesized and characterized by elemental analyses, mass, ${ }^{1} \mathrm{H}-\mathrm{NMR}$, IR, UV-vis, magnetic susceptibility and molar conductance data. The ligand (L) and its complexes have also been screened against different fungi and bacteria in vitro. The complexes exhibited potential activity at the concentration dose of $5 \mathrm{mg} / \mathrm{ml}$ which is comparable to that of tetradentate 12-membered macrocyclic compounds, shown to have antimicrobial activity against various pathogens by disc diffusion technique [40, 41].

Lei and coworkers have reported the synthesis of a series of Schiff bases (Scheme 18) by reacting 5-chlorosalicylaldehyde and primary amines. The compounds were assayed for antibacterial (Bacillus subtilis, Esherichia coli, Pseudomonas fluorescence and Staphylococcus aureus) and antifungal (Aspergillus niger, Candida albicans and Trichophyton rubrum) activities. Among the compounds tested, (E)-4-chloro-2-((4-flurobenylimino)-methyl)phenol showed the most favorable antimicrobial activity with $\mathrm{MIC}_{\mathrm{s}}$ of 45.2, 1.6, 2.8, 3.4, and $47.7 \mu \mathrm{g} / \mathrm{mL}$ against B. Subtilis, E. coli, P. flurescence, $S$. aureus and A. niger, respectively. It is also reported that Salicylaldehyde derivatives, with one or more halo-atoms in the aromatic ring, showed variety of biological activities like antibacterial and antifungal activities $[42,43]$.

Sammanta and coworkers have reported herein the synthesis three new $\mathrm{Cu}(\mathrm{II})$ complexes of tri and tetradentate Schiff base ligands (Scheme 19) containing $\mathrm{N}_{3}$ or $\mathrm{N}_{4}$ donor set along with terminal $\mathrm{NNN}^{-}$or $\mathrm{SCN}^{-}$ligands: $\left[\mathrm{L}^{1} \mathrm{Cu}(\mathrm{NCS})\right] \mathrm{ClO}_{4}(1),\left[\mathrm{L}^{2} \mathrm{Cu}(\mathrm{NCS})_{2}\right](2)$ and $\left[\mathrm{L}^{3} \mathrm{Cu}(\mathrm{NNN})\right] \mathrm{ClO}_{4}(3)\left[\mathrm{L}^{1}=\right.$ 


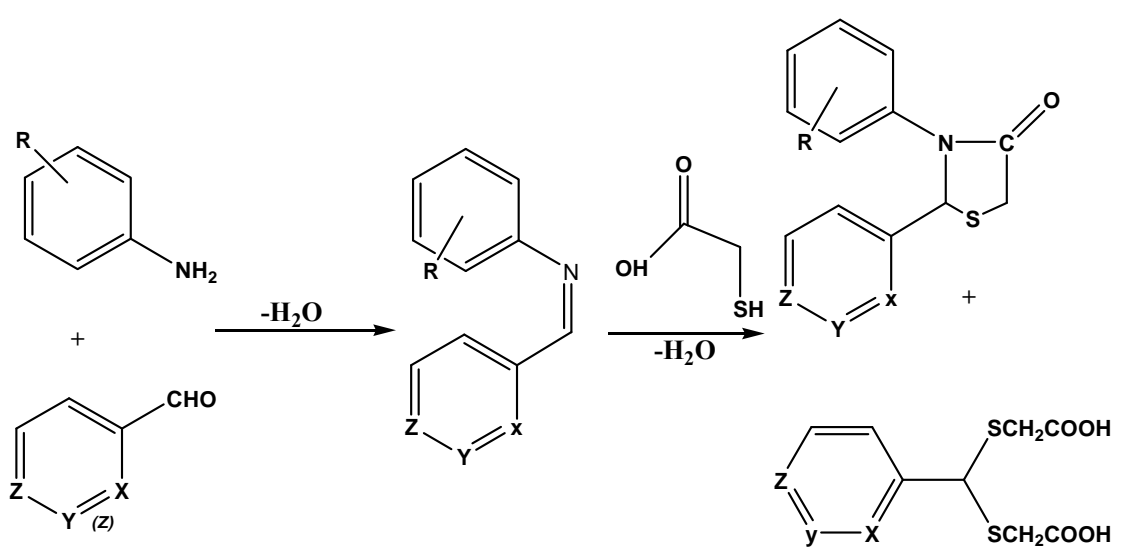

Scheme 11. Aromatic Schiff Bases and 2,3-diaryl-1,3-thiazolidin-4-one.

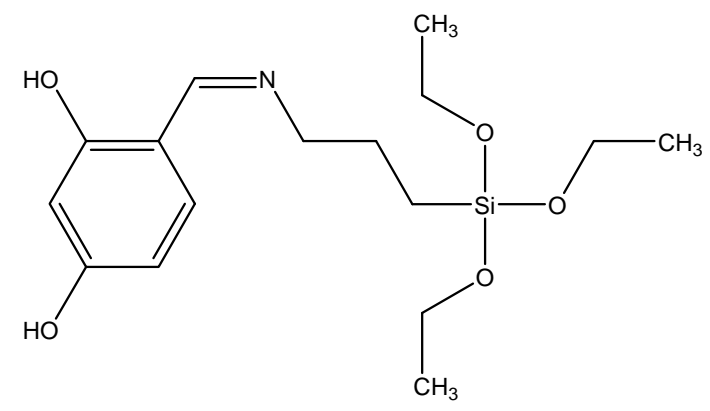

(a)

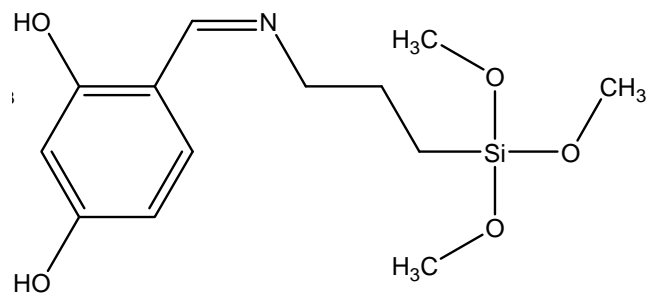

(b)

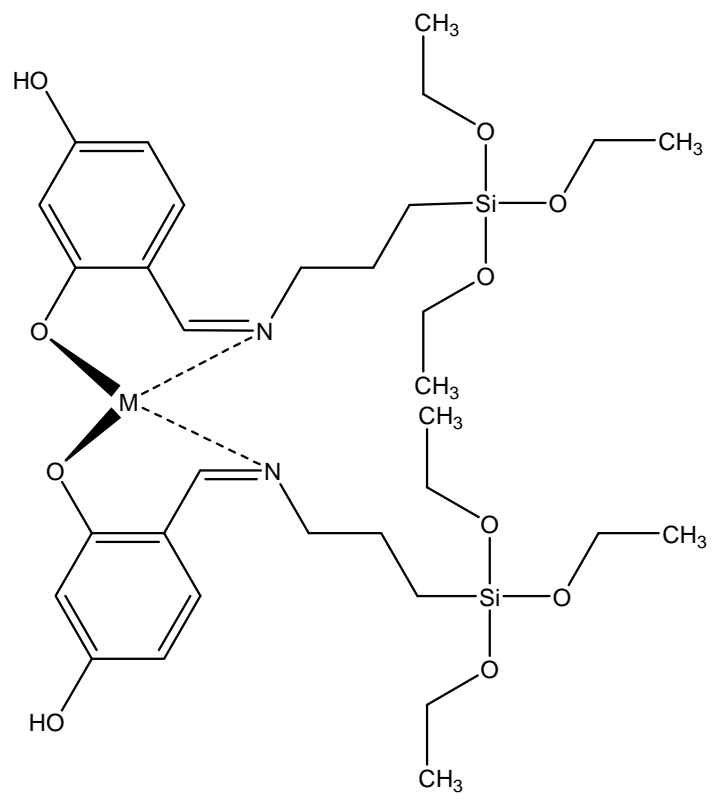

(c)

Scheme 12. (a) the proposed structure of Hesb Schiff base Ligand, (b) the proposed structure of Hmb Schiff base Ligand, (c) (a) the proposed structure of the Hesb complexes.

$\mathrm{NC}_{5} \mathrm{H}_{4} \mathrm{C}\left(\mathrm{CH}_{3}\right)=\mathrm{N}\left(\mathrm{CH}_{2}\right)_{3} \mathrm{~N}=\mathrm{C}\left(\mathrm{CH}_{3}\right) \mathrm{C}_{5} \mathrm{H}_{4} \mathrm{~N}, \mathrm{~L}^{2}=$ $\mathrm{Me}_{2} \mathrm{~N}-\left(\mathrm{CH}_{2}\right)_{3}-\mathrm{N}=\mathrm{C}\left(\mathrm{CH}_{3}\right) \mathrm{C}_{5} \mathrm{H}_{4} \mathrm{~N}$ and $\mathrm{L}^{3}=$

$\mathrm{NC}_{5} \mathrm{H}_{4} \mathrm{CH}=\mathrm{N}-\left(\mathrm{CH}_{2}\right)_{4}-\mathrm{N}=\mathrm{CH} \quad \mathrm{C}_{5} \mathrm{H}_{4} \mathrm{~N}$. Antimicrobial activities of the Schiff base ligands and their metal complexes have been studied using the disc diffusion method on the strains of Candida tropicalis and Bacillus megaterium [44].

Singh have reported the synthesis a new series of complexes (Scheme 20) by template condensation of oxalyldihydrazide and benzil in methanolic medium in 


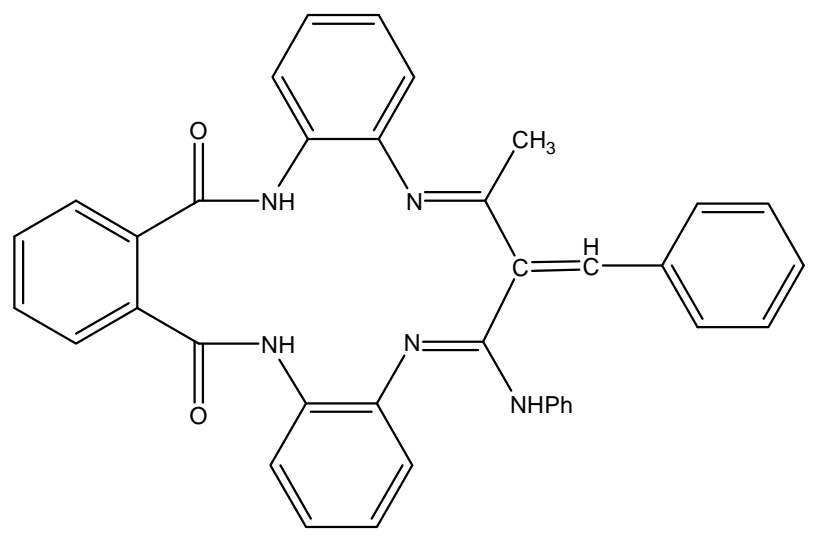

Scheme 13. Structure of macrocyclic ligand.<smiles>CC(=NCC(=O)O)c1ccccc1O</smiles>

(a)

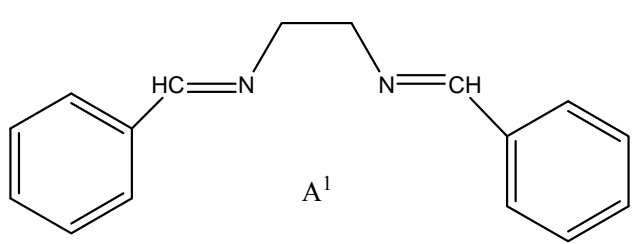

(b)

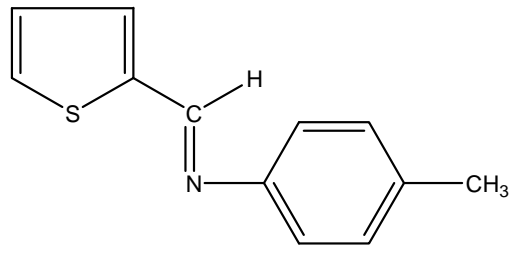

$\mathrm{A}^{2}$

(c)

Scheme 14. Structures of the Schiff bases.

the presence of trivalent chromium, manganese and iron salts complexes. The complexes have been characterized with the help of elemental analyses, conductance measurements, magnetic susceptibility measurements, electronic, NMR, infrared and far infrared spectral studies. On the basis of these studies, a five coordinate square pyramidal geometry has been proposed for all these complexes. The biological activities of the metal complexes have been tested in vitro against a number of pathogenic to assess their inhibiting potential. Some of these complexes have been found to exhibit remarkable antibacterial [45].

The complexes (Scheme 21) of $\mathrm{Co}(\mathrm{II}), \mathrm{Ni}(\mathrm{II}), \mathrm{Cu}(\mathrm{II})$, $\mathrm{Zn}(\mathrm{II}), \mathrm{Cd}(\mathrm{II}), \mathrm{Hg}(\mathrm{II})$, dioxouranium(VI), and $\mathrm{Th}(\mathrm{IV})$ with a new Schiff base, 3-[(z)-5-amino-1.3.3-trimethyl cyclohexylmethylimino]-1.3-dihydroindol-2-one formed by the condensation of isatin (Indol-2.3-dione) with isophoronediamine (5-amino-1.3.3-trimethyl-cyclohexane methylamine)(IPDA) was synthesized and characterized by microanalysis, conductivity, UV-visible, FT-IR, ${ }^{1} \mathrm{H}$ NMR, TGA, and magnetic susceptibility measurements. All the complexes exhibit 1:1 metal to ligand ratio spectral data revealed that the ligand acts as monobasic bidentate, coordinating to the metal ion through the azomethine nitrogen and carbonyl oxygen of isatin moiety. Both the ligand and the metal complexes were screened for their antibacterial activity against Bacillus subtilis, Staphylococcus aureus (S. aureus), Escherichia coli (E. coli), and Pseudomonas aeruginosa, and the complexes are more potent bactericides than the ligand [46].

Complexes of the type [M(apash)Cl] and [M(Hapash) $\left.\left(\mathrm{H}_{2} \mathrm{O}\right) \mathrm{SO}_{4}\right]$, where $\mathrm{M}=\mathrm{Mn}(\mathrm{II}), \mathrm{Co}(\mathrm{II}), \mathrm{Ni}(\mathrm{II})$, $\mathrm{Cu}(\mathrm{II})$ and $\mathrm{Zn}(\mathrm{II})$; Hapash = acetone p-amino acetophenone salicyl hydrazone have been synthesized and characterized by elemental analyses, molar conductance, magnetic moments, electronic, ESR and IR spectra, thermal studies (TGA \& DTA) and X-ray diffraction studies. The ligand coordinates through two $(\mathrm{C}=\mathrm{N})$ and a deprotonated enolate group in all the chloro complexes, whereas through two $(\mathrm{C}=\mathrm{N})$ and a $(\mathrm{C}=\mathrm{O})$ group in all the sulfato complexes. Most of the complexes show better antifungal activity than the standard miconazole against a number of pathogenic [47].

Rehman et al have reported the synthesis and characterization of a Schiff base (Scheme 22) derived from aniline and salicylaldehyde and its $\mathrm{Co}(\mathrm{II}), \mathrm{Mn}(\mathrm{II})$, and $\mathrm{Zn}$ (II) complexes; several physical, in particular, elemental analysis, infrared and NMR techniques were used to investigate the chemical structure of the complexes. Biological screening of the complexes reveals that the Schiff base transition metal complexes show significant against all microorganisms [48].

A series of new Schiff base hydrazones (Scheme 21) were synthesized by condensation reaction of 4-amino-3(4-pyridine)-5-mercapto-1,2,4-triazole with various aldehydes and/or dialdehydes. The all prepared compounds were assayed for antibacterial (Escherichia coli and Staphylococcus aureus) and antifungal (Candida albicans) activities by disc diffusion method. The results indicate that all tested compounds did not show any antibacterial activity against $E$. coli, as gram negative bacteria, and antifungal activity against $C$. albicans. But the compounds containing 4-Cl, 4-Me, 4-MeO, 2,4-di-Cl and 2-OH substituted phenyl moiety, respectively, showed good inhibition against $S$. aureus as compare to standard drugs [49].

A series of oxovanadium complexes with mixed ligands, a tridentate ONO-donor Schiff base ligand (Scheme 22) 


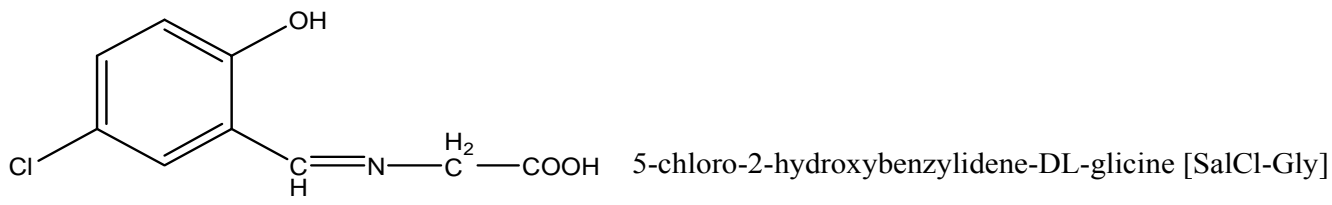<smiles>O=C(O)CN=Cc1cc(Br)ccc1O</smiles><smiles>CC(N=Cc1cc(Cl)ccc1O)C(=O)O</smiles><smiles>CC(N=Cc1cc(Br)ccc1O)C(=O)O</smiles>

5-bromo-2hydroxylidene-DL-alanin [SalBr-Ala]

Scheme 15. Amino Acid-Schiff Bases.

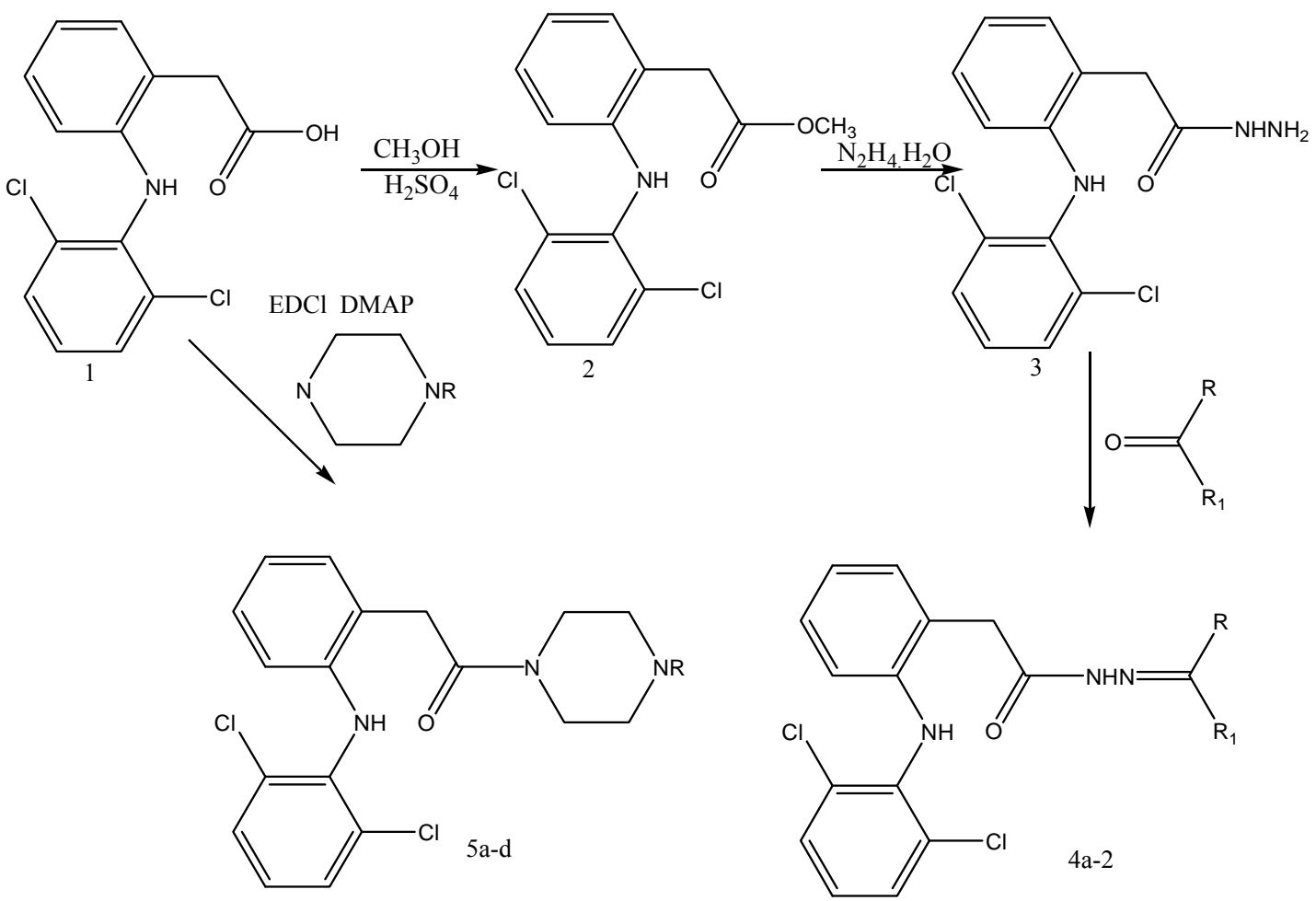

Scheme 16. Synthesis protocol of dicofenac acid hydrazones and amides.

[viz., salicylidene anthranilic acid (SAA)], and a bidentate NN ligands [viz., 2.2'-bipyridine (bpy), 1.10-phenanthroline (phen), dipyrido[3.2-d:2'.3'-f] quinoxaline (dpq), dipyrido[3.2-a:2'.3'-c] phenazine (dppz), or 7- methyldipyrido[3.2-a:2'.3'-c] phenazine (dppm)], have been synthesized and characterized by elemental analysis, electrospray ionization mass spectrometry, UV-vis spectroscopy, Fourier transform IR spectroscopy, EPR spec- 

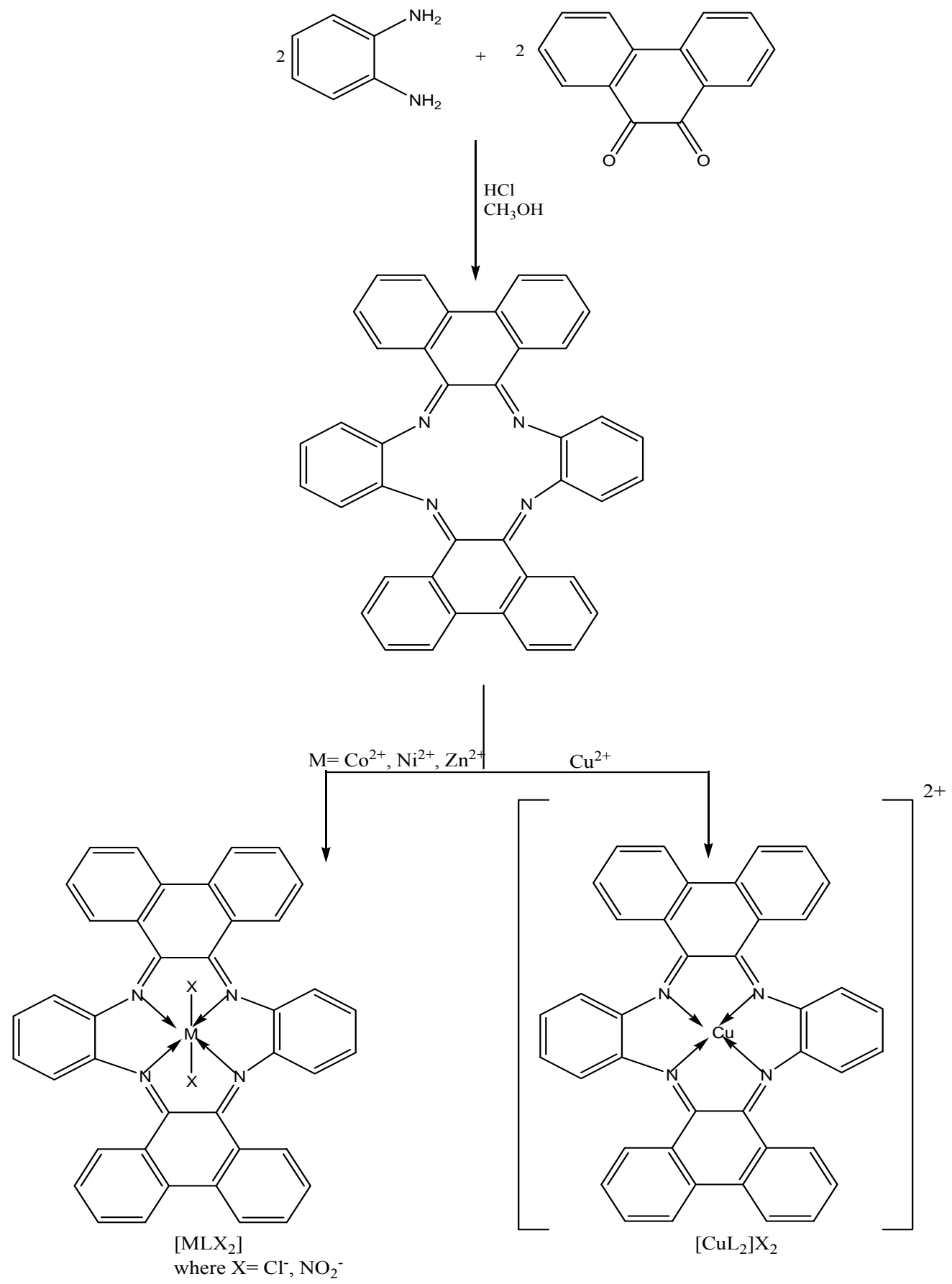

Scheme 17. Synthetic Scheme of the macrocylic ligand(L) and its complexes (where $\mathrm{X}=\mathrm{Cl}^{-}, \mathrm{NO}_{3}^{-}$).

troscopy, and X-ray crystallography. The complexes have been found to be potent inhibitors against human protein tyrosine phosphatase $1 \mathrm{~B}$ (PTP1B) $\left(\mathrm{IC}_{50}\right.$ approximately $30-61 \mathrm{nM}$ ), T-cell protein tyrosine phosphatase (TCPTP), and Src homology phosphatase 1 (SHP-1) in vitro. Interestingly, the $\left[\mathrm{V}^{\mathrm{IV}} \mathrm{O}(\mathrm{SAA})(\right.$ bpy)] complex selectively inhibits PTP1B over the other two phosphatases (approximate ninefold selectivity against SHP-1 and about twofold selectivity against TCPTP). Kinetics as- says suggest that the complexes inhibit PTP1B in a competitive and reversible manner. These suggest that the complexes may be promising candidates as novel antidiabetic agents [50].

New complexes of a Schiff (Scheme 25) derived from 2-hydroxy-5-chloroaceto phenone and glycine with $\mathrm{Mn}(\mathrm{II}), \mathrm{Fe}(\mathrm{II}), \mathrm{Co}(\mathrm{II}), \mathrm{Ni}(\mathrm{II}), \mathrm{Cu}(\mathrm{II}), \mathrm{Zn}(\mathrm{II}), \mathrm{Cd}(\mathrm{II})$, and $\mathrm{UO}_{2}(\mathrm{VI})$ have been synthesized. Antibacterial activites of the ligand and its metal complexes have been determined 


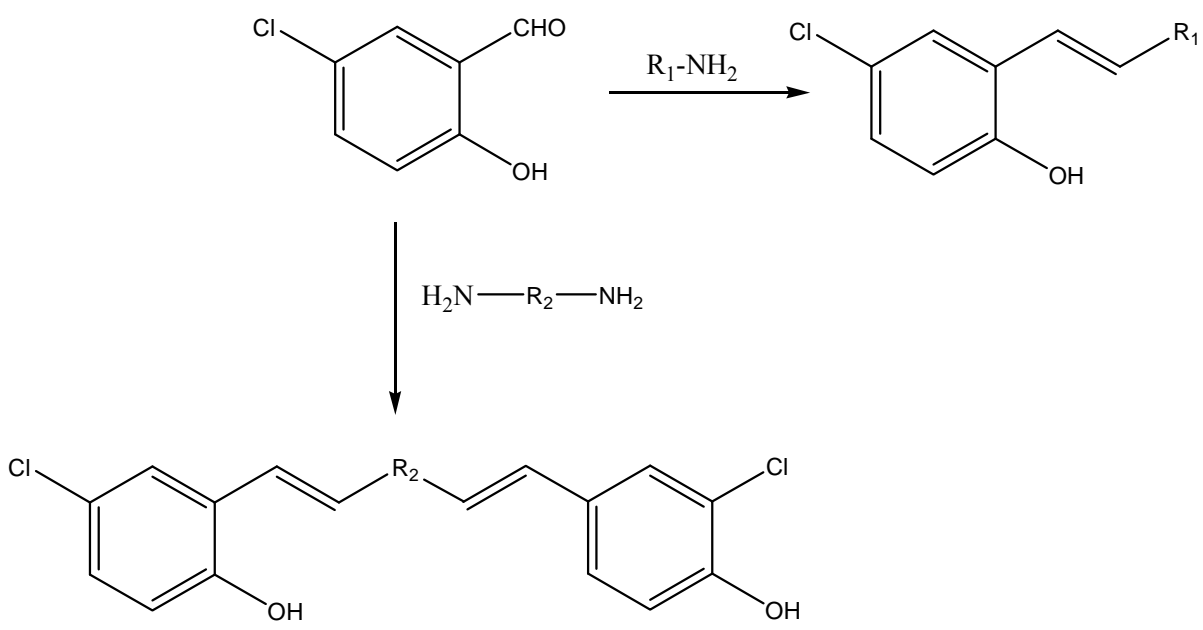

Scheme 18. Syntheses of the Schiff bases.

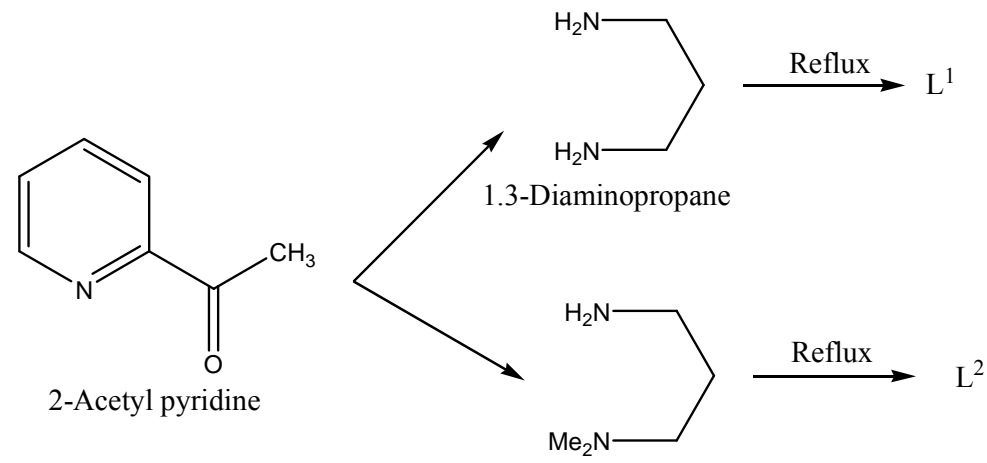

N.N-Dimethyl-1.3-diaminopropane<smiles>O=Cc1ccccn1</smiles>

Pyridine-2-carboxaldehyde

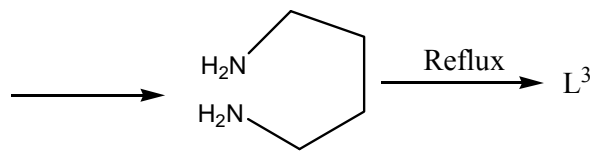

1.4-Diaminobutane

Scheme 19. Syntheses of Schiff base ligands.

by screening the compounds against various $\operatorname{Gram}(+)$ and $\operatorname{Gram}(-)$ bacterial strains. The solid state d. c. electrical conductivity of the ligand and its complexes has been measured over $313-398 \mathrm{~K}$ and the complexes were found to be of semiconducting nature [51].

The synthesis and characterization were reported of four iron(III) complexes (Scheme 26) of general formula $\left[\mathrm{Fe}\right.$ (pythsalX)- $\left.\left(\mathrm{H}_{2} \mathrm{O}\right)_{2}\right] \mathrm{Cl}_{2}$, derived from the NSNO-donor tetradentate Schiff base ligands pythsalHX ([5-X-N(2-pyridylethylsul-fanylethyl) salicylideneimine] ( $\mathrm{X}=\mathrm{OMe}$, $\mathrm{N}_{2} \mathrm{PH}, \mathrm{I}, \mathrm{NO}_{2}$ ). The free Schiff bases and their complexes have been screened for antimicrobial activities and the results show that the free Schiff bases are more potent antibacterial than the complexes [52].

Singh and coworkers have reported the synthesis a novel series of macrocyclic complexes (Scheme 27) by template condensation of 1,8-diamino naphthalene and benzil in the presence of trivalent metal salts in methanolic medium. These metal complexes were also tested for their in vitro antimicrobial activities to assess their inhibiting potential [53].

Reactions of $\left[\mathrm{RuCl}_{2}(\mathrm{DMSO})_{4}\right]$ with some of the biologically active macrocyclic Schiff base ligands (Scheme 28) containing $\mathrm{N}_{4}$ and $\mathrm{N}_{2} \mathrm{O}_{2}$ donor group yielded a number of stable complexes, effecting complete displacement of DMSO groups from the complex. The interaction of tetradentate ligand with $\left[\mathrm{RuCl}_{2}(\mathrm{DMSO})_{4}\right]$ gave neutral complexes of the type $\left[\mathrm{RuCl}_{2}(\mathrm{~L})\right]$ [where $\mathrm{L}=$ tetradentate macrocyclic ligand]. All the macrocycles and macrocyclic $\mathrm{Ru}(\mathrm{II})$ complexes along with existing antibacterial 

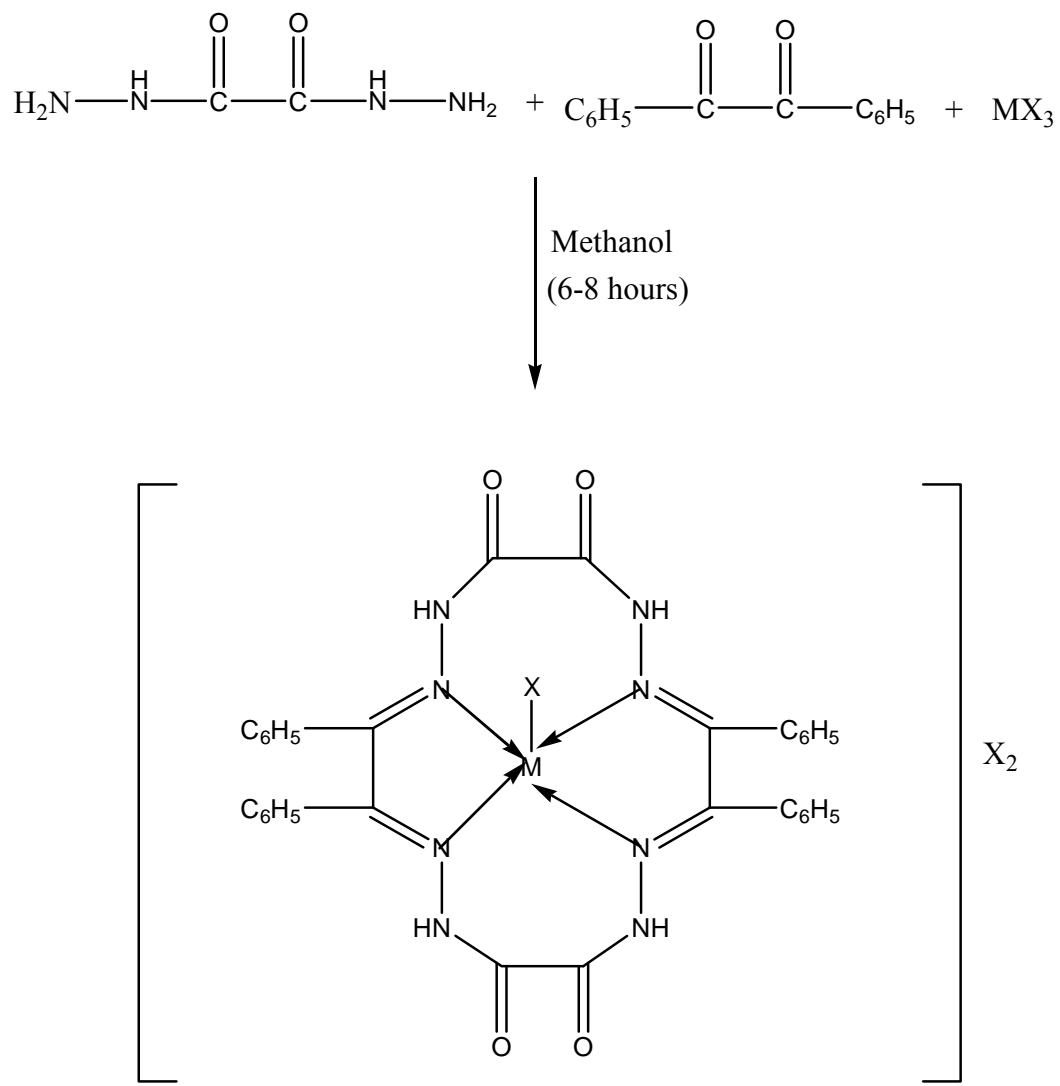

where $\mathrm{M}=\mathrm{Cr}(\mathrm{III}), \mathrm{Mn}(\mathrm{III}), \mathrm{Fe}(\mathrm{III})$, $\mathrm{X}=\mathrm{Cl}^{-}, \mathrm{NO}_{3}^{-}, \mathrm{CH}_{3} \mathrm{COO}^{-}$

Scheme 20. Synthesis a new series of Complexes.

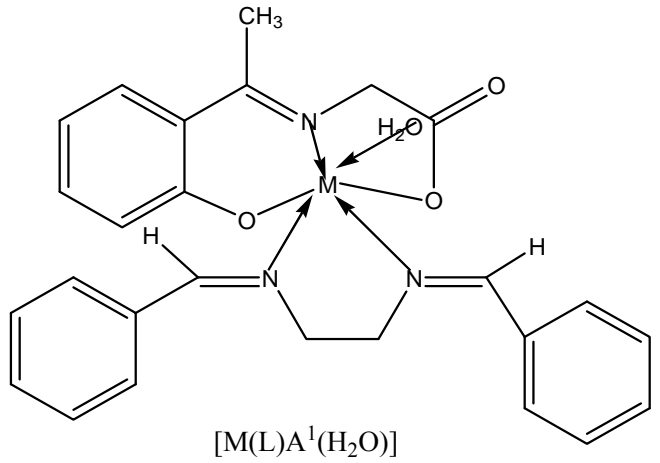

(a)

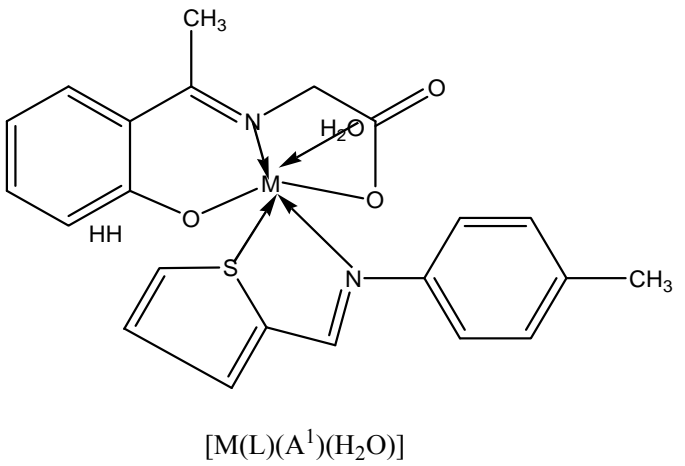

(b)

Scheme 21. Suggested structure of the mixed complexes.

drugs were screened for antibacterial activity against Gram $(+)($ Bacillus subtilis, Staphylococcus aureus) and Gram(-) (Escherichia coli, Klebsiella pneumonia) bacteria. All these compounds were found to be more active when compared to streptomycin and ampicillin. The representative macrocyclic Schiff bases and their complexes were also tested in vitro to evaluate their activity against fungi, namely, Aspergillus flavus and Fusarium species [54].
A novel Schiff base ligand (Scheme 29) derived from 5-bromo salicylicaldehyde and 4-substituted amines and its transition complexes with $\mathrm{Co}(\mathrm{II}), \mathrm{Ni}(\mathrm{II})$ and $\mathrm{Cu}(\mathrm{II})$ have been synthesized. The antimicrobial activity properties of the ligands and their metal complexes have been studied [55].

4-Phenyl-5-pyridin-4-yl-4H-1,2,4-triazole-3-thiol (Scheme 30) was obtained in basic media via the formation of 2-isonicotinoyl-N-phenylhydrazinecar bothioamide 
(2), and converted to some alkylated derivatives and Mannich base derivatives. 2-[(4-Phenyl-5-pyridin-4-yl4H-1,2,4-triazol-3-yl)thio]acetohydrazide (7) that was obtained by using compound 3 as precursor in two steps was converted to thiosemicarbazide derivative (8), Schiff base derivatives (9) and 5-\{[(4-phenyl-5-pyridin-4-yl4H-1,2,4-triazol-3-yl)thio]methyl $\}-1,3$,4-oxadiazole-2-thi ol(10). Moreover, (Scheme 30) 5-\{[(4-phenyl-5-pyridin4-yl-4H-1,2,4-triazol-3-yl)thio] methyl $\}-3-\{[(2-m o r p h o l i n-$ 4-yleth yl)amino]methyl $\}$-1,3,4-oxadiazole-2(3H)-thione (11) was synthesized via reaction of compound 10 with 2-(4-morpholino)ethylamine. The treatment of compound 8 with $\mathrm{NaOH}$ gave 4-(4-methylphenyl)-5-\{[(4-phenyl-5pyridine-4-yl-4H-1,2,4-triazol-3-yl)thio]methyl $\}-4 \mathrm{H}-1,2$, 4-triazole-3-thiol (12), while the acidic treatment of compound 8 afforded 5-\{[(4-phenyl-5-pyridin-4-yl-4H-1,2,4triazol-3-yl)thio]methyl -2(4-methylphenyl)-amino-1,3, 4-thiadiazole. All newly synthesized compounds were screened for their antimicrobial activities. The antimicrobial activity study revealed that all the compounds screened showed good or moderate activity except compounds 3, 5, 7, 9, 9, and 11 [56].

Microwave-assisted synthesis and characterization of the organotin (IV) complexes (Scheme 31) are reported. Trigonal bipyramidal and octahedral complexes of tin (IV) have been synthesized by the reaction of dimethyltin (IV) dichloride with 4-nitrobenzanilide-S-benzyldithiocarbazate $\left(\mathrm{L}_{1} \mathrm{H}\right)$, 4-chlorobenzanilide-S-benzyldithiocarbazate $\left(\mathrm{L}_{2} \mathrm{H}\right)$, 4-nitrobenzanilidebenzothiazoline $\left(\mathrm{L}_{3} \mathrm{H}\right)$ and 4-chlorobenzanilidebenzothiazoline $\left(\mathrm{L}_{4} \mathrm{H}\right)$. The antimicrobial activities of the ligands and their correspond- ing organotin (IV) complexes have been screened against various strains of bacteria and fungi. Antifertility activity against male albino rats has also been reported [57].

A media consisting of isatin-Schiff bases (Scheme 32) (isatin-3-thiosemicarbazone, isatin-3-semicarbazone, and isatin-3-phenylhydrazone) was developed to maximize the production of antibiotics Hexaene H-85Azalomycine B by Streptomyces hygroscopicus. The media isatin-3thiosemicarbazone resulted in the maximum antibiotics concentration of $372 \mu \mathrm{g} \cdot \mathrm{cm}^{-3}$ for Hexaene $\mathrm{H}-85$ and 118 $\mu \mathrm{g} \cdot \mathrm{cm}^{-3}$ for Azalomycine B [58].

Two end-on azido-bridged $\mathrm{Co}(\mathrm{III})$ complexes $\left[\mathrm{Co}_{3}(\mathrm{~L} 1)\left(\mu_{1,1}-\mathrm{N}_{3}\right)_{4}\left(\mathrm{~N}_{3}\right)_{2}\left(\mathrm{OH}_{2}\right)\left(\mathrm{OCH}_{2} \mathrm{CH}_{3}\right)\right] .0 .5 \mathrm{H}_{2} \mathrm{O}$<smiles></smiles>

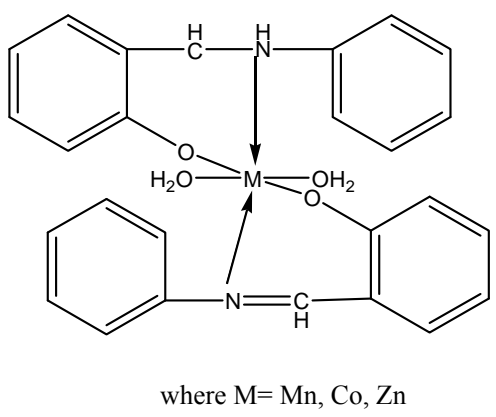

Scheme 22. Complexes of the type [M(apash)Cl] and $\left[\mathrm{M}(\mathrm{Hapash})\left(\mathrm{H}_{2} \mathrm{O}\right) \mathrm{SO}_{4}\right]$.

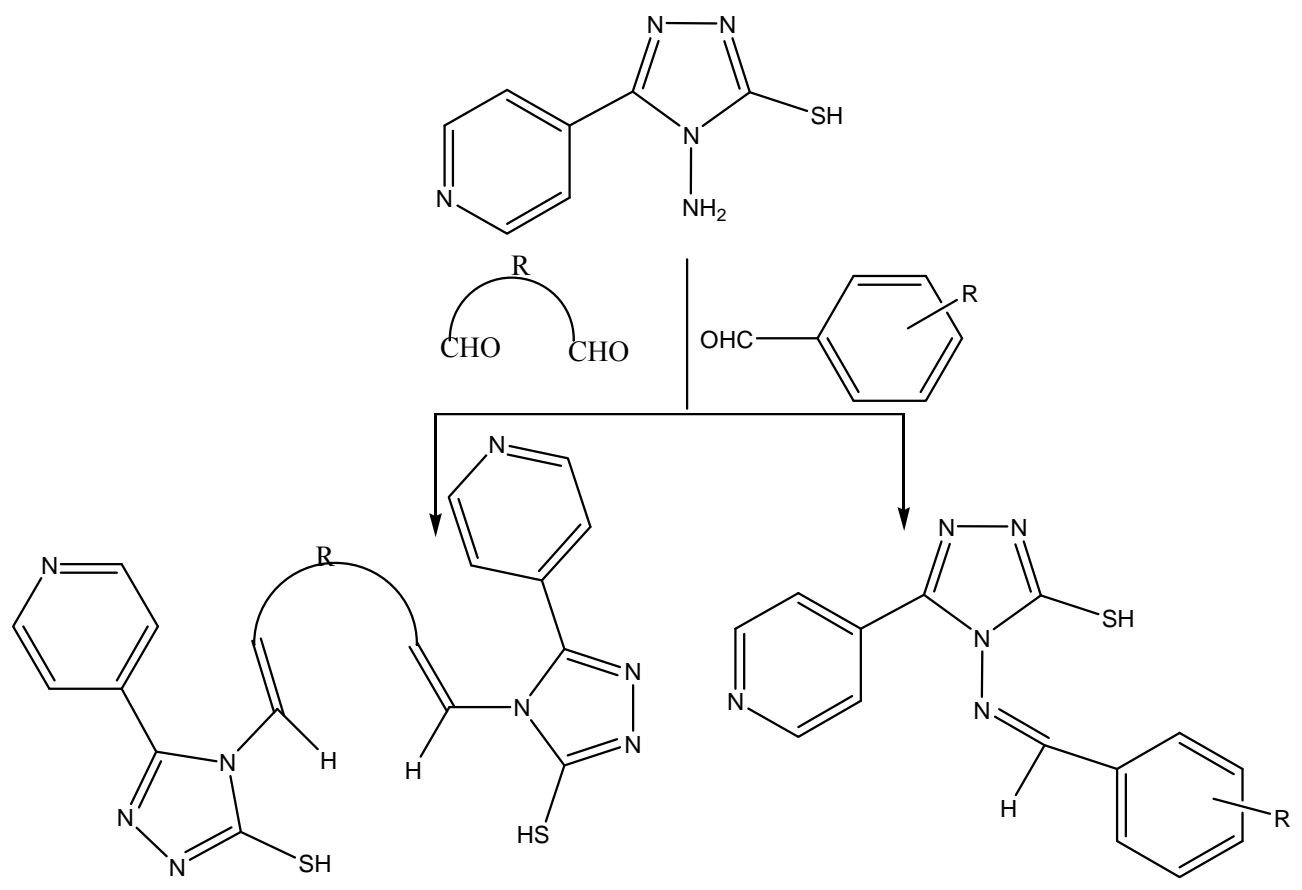

Scheme 23. The synthesized hydrazones. 


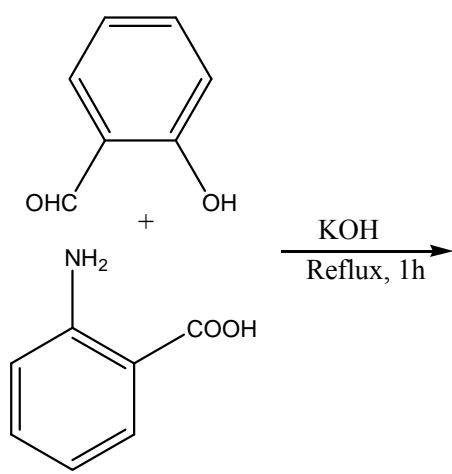

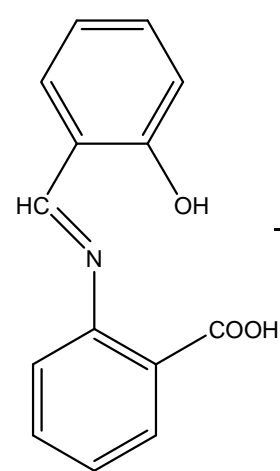

SAA

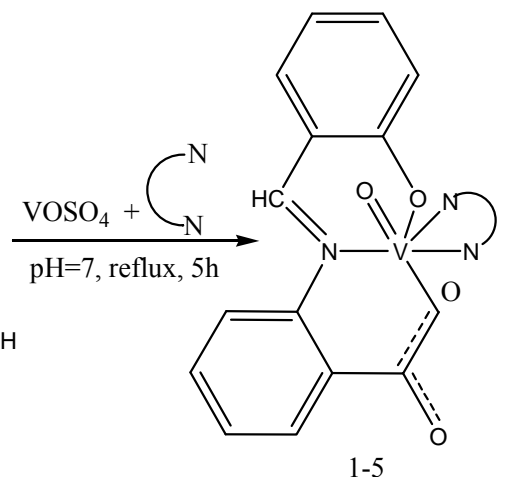

$1-5$

$\overbrace{\mathrm{N}}^{\mathrm{N}}=$ ppy, phen, dpq, dppz, dppm

Scheme 24. The synthesis of the complexes, SAA Salicylidene anthranilic acid, bpy 2.2'-bipyridine, phen 1.10-phenanthroline dpq dipyrido[3.2-d; 2'.3'-f] quinoxaline, dppz dipyrido[3.2-a;2'.3'-c] phenazine, dppm 7-methyldipyrido[3.2-a; 2',3'-c] phenazine.

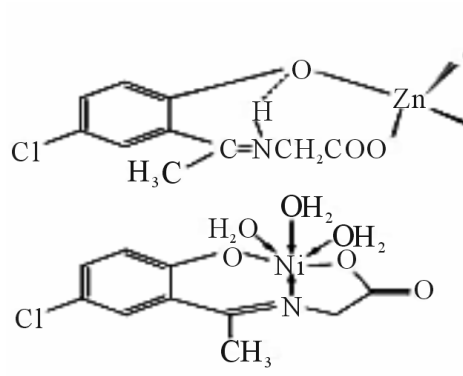<smiles>CC1C2CN(CC(O)O2)[Si](O)(O)OC2CC=C(Cl)CC21</smiles>

$\mathrm{N}$<smiles>C[C@H]1N[CH]O[C@@H]2CC[C@@H](Cl)C[C@H]12</smiles><smiles>ClCCl</smiles>

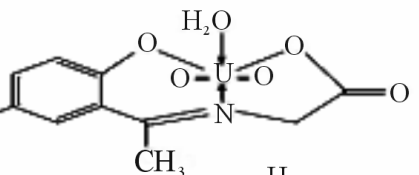

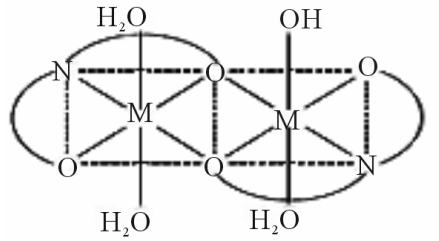

$\mathrm{M}=\mathrm{Mn}, \mathrm{Fe}, \mathrm{Cd}$ Scheme

Scheme 25. Synthesis New complexes of a Schiff Bases derived from 2-hydroxy-5-chloroaceto phenone and glycine with M(II).

and $\left[\mathrm{Co}_{2}(\mathrm{~L} 2)_{2}\left(\mu_{1,1}-\mathrm{N}_{3}\right)_{2}\left(\mathrm{~N}_{3}\right)_{2}\right](2)$, where L1 and L2 are the deprotonated form of 5-methoxy-2-[2-morpholin4-ylethy-limino) methyl]phenol and 2-ethoxy-6-[2-morpholin-4-ylethy-limino)methyl] phenol, respectively, were prepared and structurally characterized by physiochemical and spectroscopic methods and single crystal X-ray determination. Complex (1) is a trinuclear Co compound, while complex (2) is a centrosymmetric dinuclear Co compound. In both complexes, the Co atoms are in octahedral coordination. The preliminary biological tests show that the complexes have excellent antibacterial activity [59].
Singh et al have reported the synthesis new $\mathrm{Zn}(\mathrm{II})$ complexes (Scheme 33) by the reactions of zinc(II) acetate with Schiff bases derived from 3-substituted phenyl4-amino-5-hydrazino-1,2,4-triazole and benzaldehyde, 2hydroxyacetophenone or indoline-2,3-dione. All these complexes are soluble in DMF and DMSO; low molar conductance values indicate that they are non-electrolytes. All these Schiff bases and their complexes have also been screened for their antibacterial activities against Bacillus subtilis, Escherichia coli and antifungal activities against Colletotrichum falcatum, Aspergillus niger, Fusarium oxysporium and Carvularia pallescence 

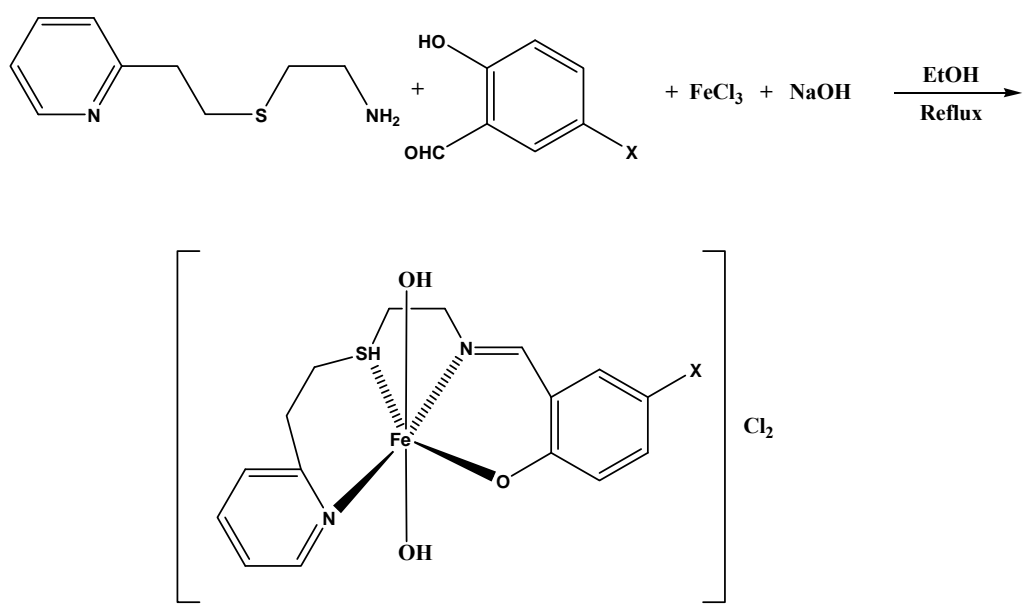

Scheme 26. Preparation of complexes $\mathrm{X}=\mathrm{I}, \mathrm{NO}_{2}, \mathrm{OMe}, \mathrm{N}_{2} \mathrm{Ph}$.<smiles></smiles>

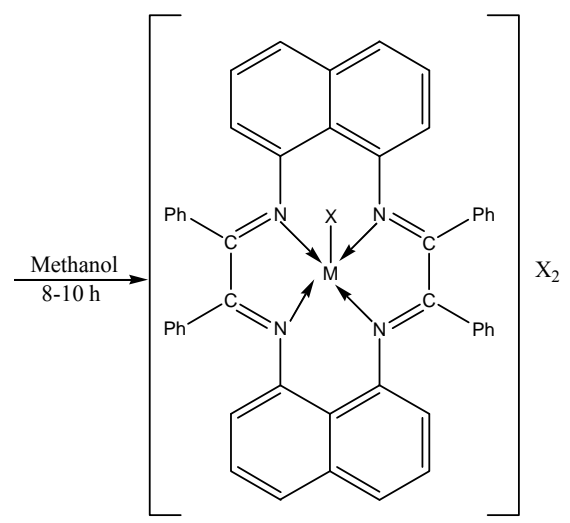

Where $\mathrm{M}=\mathrm{Cr}(\mathrm{III}), \mathrm{Mn}(\mathrm{III}), \mathrm{Fe}(\mathrm{III})$ $\mathrm{X}=\mathrm{Cl}^{-}, \mathrm{NO}_{3}{ }_{3}, \mathrm{CH}_{3} \mathrm{COO}^{-}$

Scheme 27. Synthesis of Novel series of Macrocyclic Complexes.

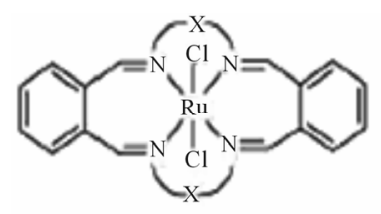

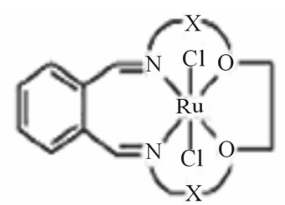

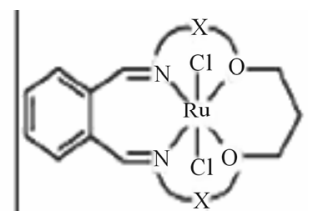

Scheme 28. Structure of macrocylic Ru(II) compounds.

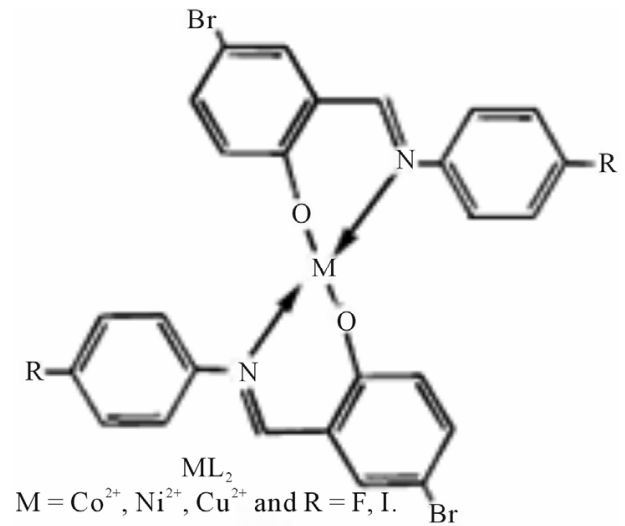

Scheme 29. General structure of metal complex. by petriplates methods [60].

Schiff base; N,N' bis(2-hydroxy-1-naphthaldimine)1,3-diaminopropanol (napdapOH) reacts with metal chlorides to form dinuclear complexes of the type $\left[\mathrm{M}_{2} \mathrm{~L}_{2}\right] \mathrm{nCl}_{2}$ where $\mathrm{M}=\mathrm{Ni}, \mathrm{Cu}, \mathrm{Fe}$ and $\mathrm{n}=0.1$ Schiff base complexes were characterized by using FT-IR, LC- MS, magnetic moments and conductance measurements. Coordination was found to be through the phenolic oxygen atoms and azomethine nitrogen atoms. The electronic properties of the compounds were investigated theoretically by performing semi-empirical molecular orbital theory PM3 method in Hyperchem 7 (Release). The antibacterial activities of the compounds were investigated against Escherichia coli ATCC 11230, Bacillus subtilis RSKK 244, 


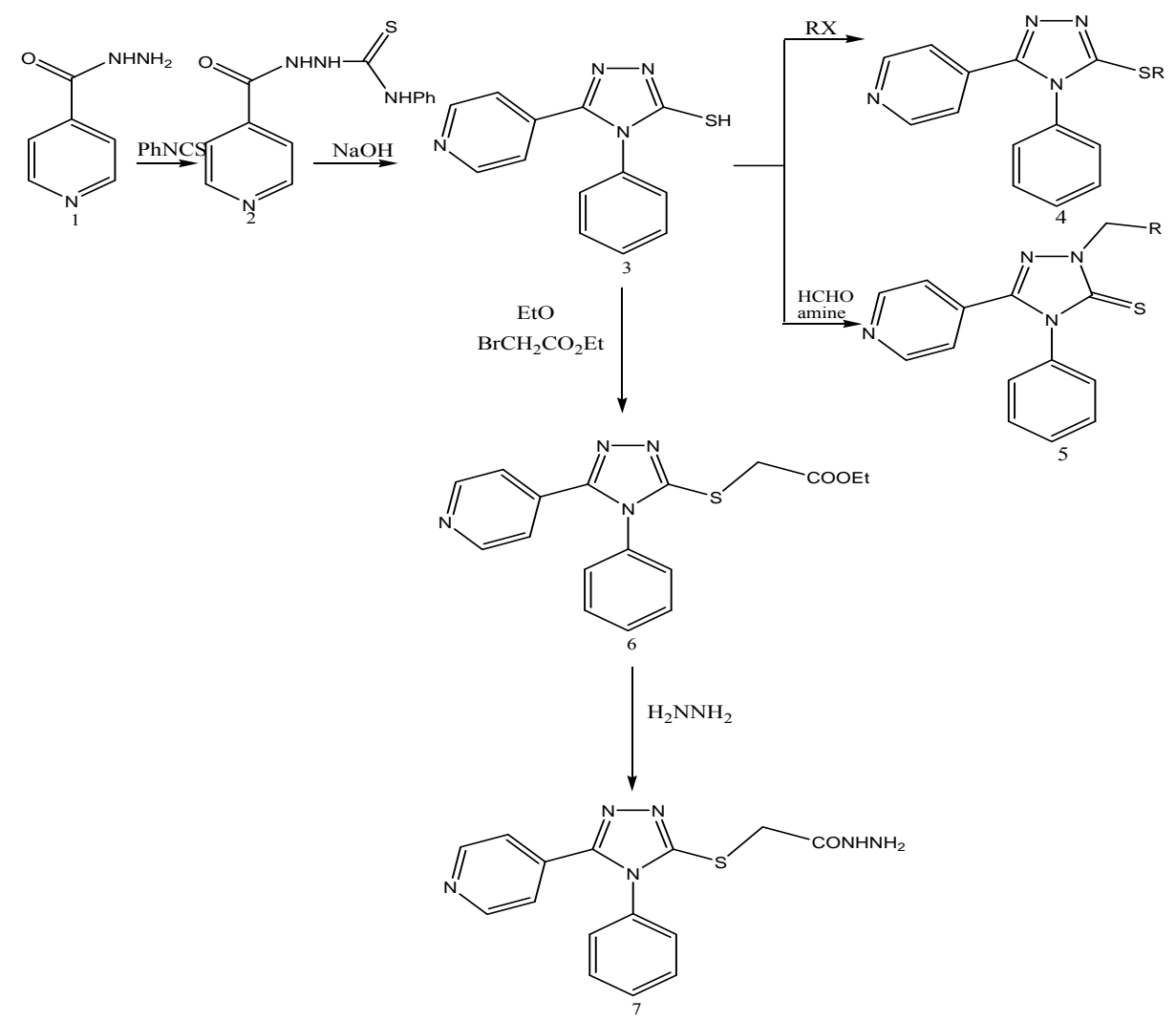

(a)
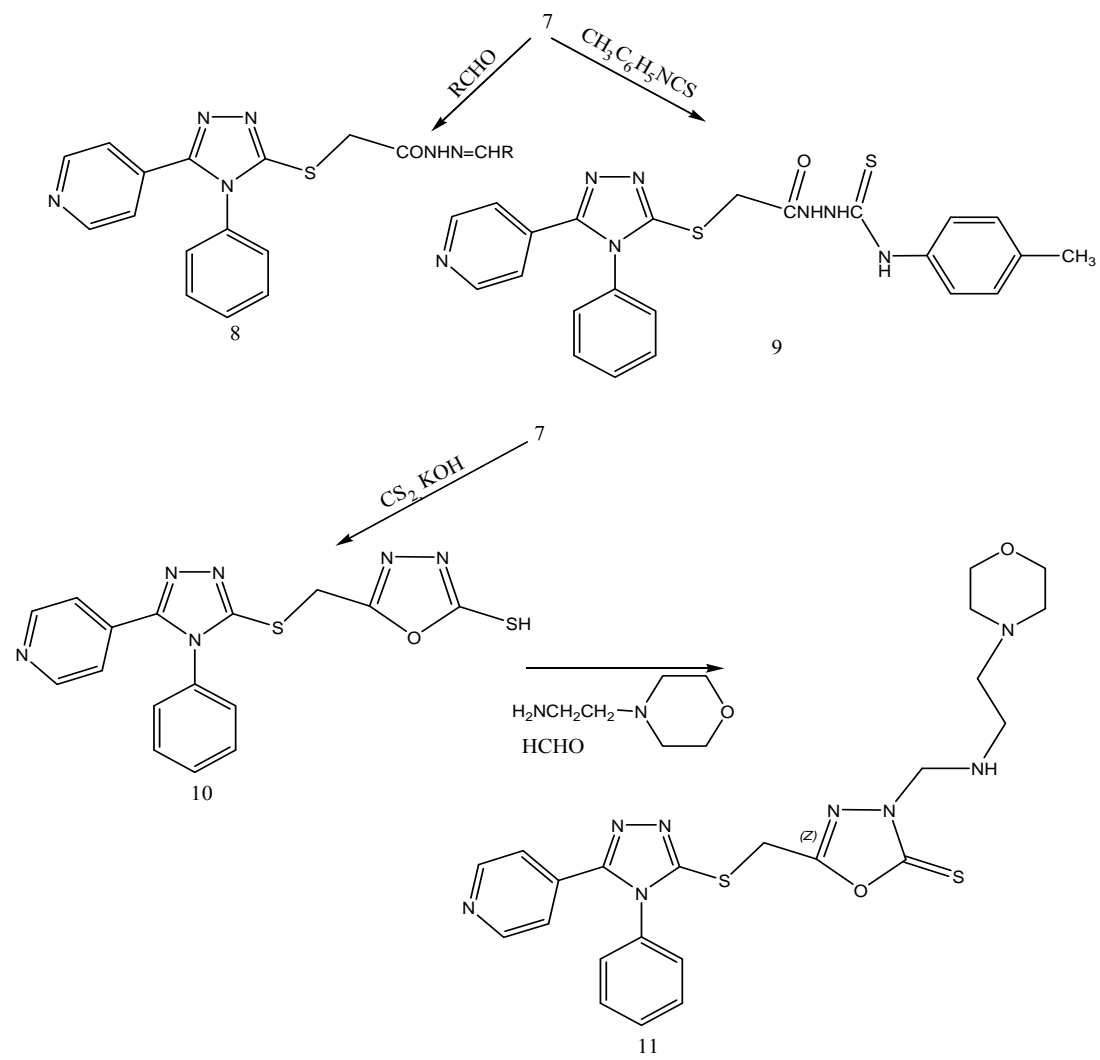

(b)

Scheme 30. Synthesis pathway for the preparation of compounds 2 - 11 . 


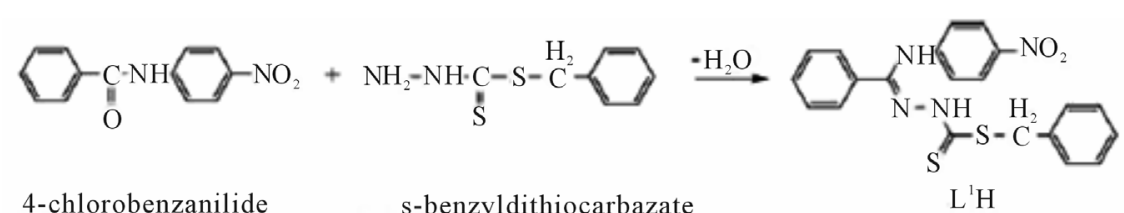

(a)

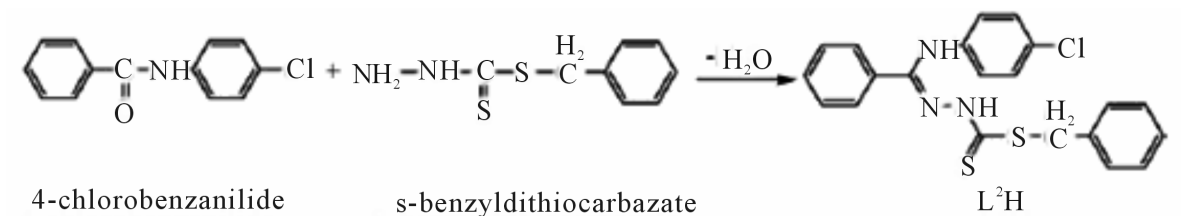

(b)

Scheme 31. Synthesis of $L^{1} H$ and $L^{2} H$.<smiles>NC(=S)NN=C1C(=O)Nc2ccccc21</smiles>

isatin-3-thiosemicarbazone<smiles>O=CNN=C1C(=O)Nc2ccccc21</smiles>

isatin-3-semicarbazone

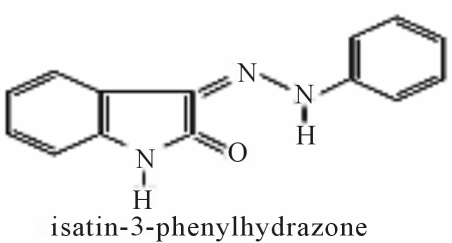

Scheme 32. Structures of Schiff bases.

Bacillus megaterium RSKK 5117, Salmonella enteritidis ATCC 13076, Staphylococcus aureus ATCC 25923 by using microdilution method [61].

Plech et al have proved that chemical character of the C-5 substituent significantly determines the antibacterial activity of the Mannich bases (Scheme 34) derived from 4,5-disubstituted 1,2,4-triazole-3-thiones. This activity was considerably increased by an introduction of a bromine atom to the phenyl ring. The obtained compounds were particularly active against opportunistic bacteria (Bacillus subtilis and Bacillus cereus). The antibacterial activity of some Mannich bases was similar or higher than the activity of commonly used antibiotics such as ampicillin and cefuroxime [62].

Schiff base ligand $\left(\mathrm{H}_{3} \mathrm{~L}\right)$ was prepared from the condensation reaction of protochatechualdehyde (3,4-dihydroxybenzaldhyde)with 2-amino phenol. From the direct reaction of the ligand $\left(\mathrm{H}_{3} \mathrm{~L}\right)$ with $\mathrm{Co}(\mathrm{II}), \mathrm{Ni}(\mathrm{II})$ and $\mathrm{Cu}(\mathrm{II})$ chlorides, and $\mathrm{Fe}(\mathrm{III})$ and $\mathrm{Zn}(\mathrm{II})$ nitrates in 2:1 L molar ratio, the five new neutral complexes were prepared. The characterization of the newly formed compounds was done by ${ }^{1} \mathrm{H}-\mathrm{NMR}$, UV-Vis, and IR spectroscopy and elemental analysis. The in vitro antibacterial activity of the metal complexes was studied and compared with that of free ligand [63].

Kalanithi et al have reported the synthesis tridentate chelate complexes (Scheme 35) of $\mathrm{Co}(\mathrm{II}), \mathrm{Ni}(\mathrm{II}), \mathrm{Cu}(\mathrm{II})$ and $\mathrm{Zn}(\mathrm{II})$ from the chalcone based ligands 2-[1-(3(1H-imidazol-1-yl)propylimino)-3-(phenylallyl)]phenol (HL1), 2-[1-(3-(1H-imidazol-1-yl)propylimino)-3-p-tolylallyl] phenol $\left(\mathrm{HL}_{2}\right), 2-[1-(3-(1 \mathrm{H}-$ imidazol-1-yl) propylimino)-3-4-nitrophenylallyl] phenol $\left(\mathrm{HL}_{3}\right)$. The anti-microbial activity of the ligands and metal(II) complexes against the species Pseudomonas aeruginosa, Escherichia coli, Staphylococcus aureus, Bacillus subtilis, Candida albigans and Aspergillus niger has been carried out and compared [64].

Ugras et al have reported the synthesis, complexation, antifungal and antibacterial activity studied of a new macro cyclic Schiff base (Scheme 36) [65].

Preparation, physical characterization and antibacterial activity of Ni(II) Schiff base complex was reported by Morad et al. [65].

Synthesis and pharmacological studies of novel Schiff bases of 4-Hydroxy 6-carboxyhydrazino benzofuran (Scheme 37) was reported by Gopal Krishna Rao et al. [65].

4-Chloro-2-oxo-2H-chromene-3-carbaldehyde was made to react with different anilines in rectified spirit to yield a series of Schiff bases (Scheme 38) of type 4-chloro3-(substituted-phenylimino)methyl)-2H-chromen-2-one. These compounds were characterized in the basis of their spectral (IR, ${ }^{1} \mathrm{H}$ NMR) data and evaluated for antimicrobial activity in vitro against fungi, gram positive and gram negative bacteria [65].

Vijey et al have reported the synthesis of a series of 1-(5-substituted-2-oxoindolin-3-ylidene)-4-(substituted-p yridin-2-yl)thiosemicarbazide (Scheme 39) derivatives. 


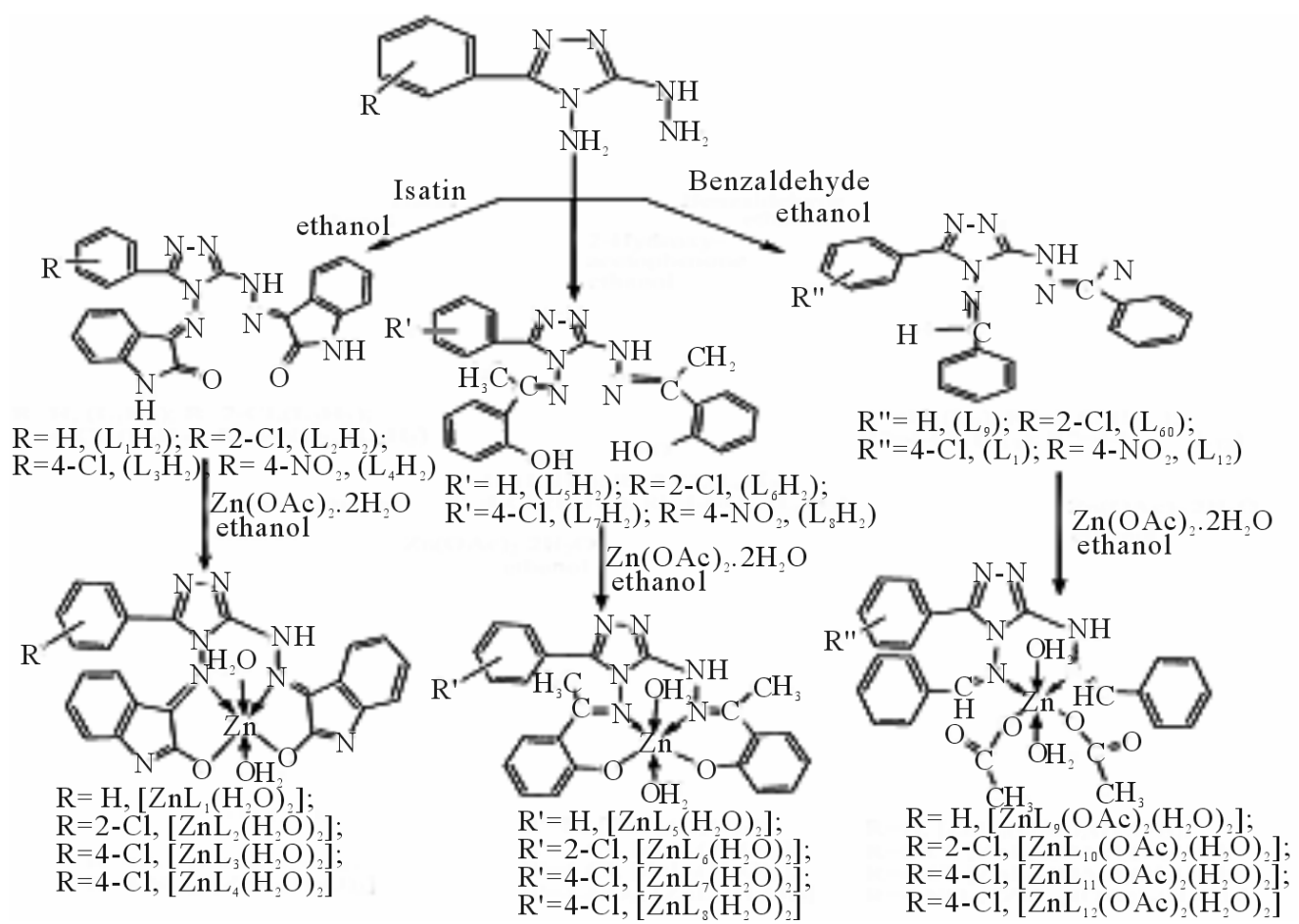

Scheme 33. Reaction scheme for the preparation of Schiff bases and their zinc(II) complexes.<smiles>[R]c1cccc(C(=O)NNC(=S)Nc2ccc(Br)cc2)c1</smiles><smiles>[R]Cn1nc(-c2ccccc2[R])n(-c2ccc(Br)cc2)c1=S</smiles><smiles>[R]c1cccc(-c2n[nH]c(=S)n2-c2ccc(Br)cc2)c1</smiles>

Scheme 34. Synthetic route to target compounds.

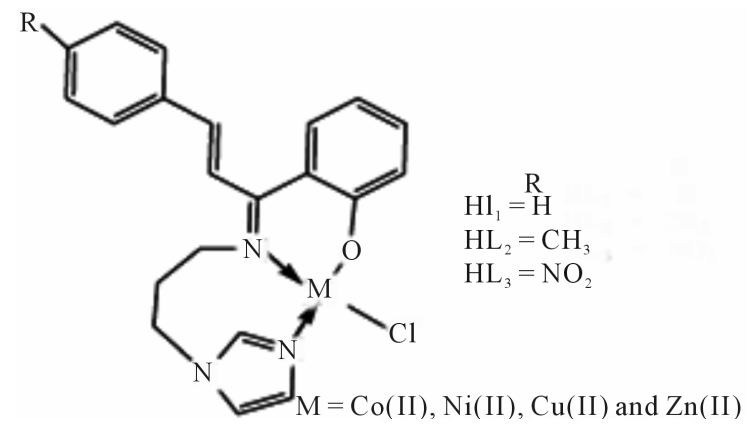

Scheme 35. Proposed structure of the metal(II) complexes.
Theses compounds were screened for in vitro antibacterial and antifungal activity against $B$. subtilis, $S$. aureus, E. Coli, $P$ aeruginosa, C. albicans, and A. niger. All the compounds were reported to exhibit moderate to good antibacterial and antifungal activity [65].

A series of biologically active pyrazine-derived Schiff base ligands (Scheme 40) have been synthesized by the condensation reaction of 2-aminopyrazine with salicylaldehyde and acetamidobenzylaldehyde. Then their $\mathrm{Co}(\mathrm{II}), \mathrm{Ni}(\mathrm{II}) \& \mathrm{Zn}(\mathrm{II})$ complexes have been prepared. The biological evaluation of the simple uncomplexed 


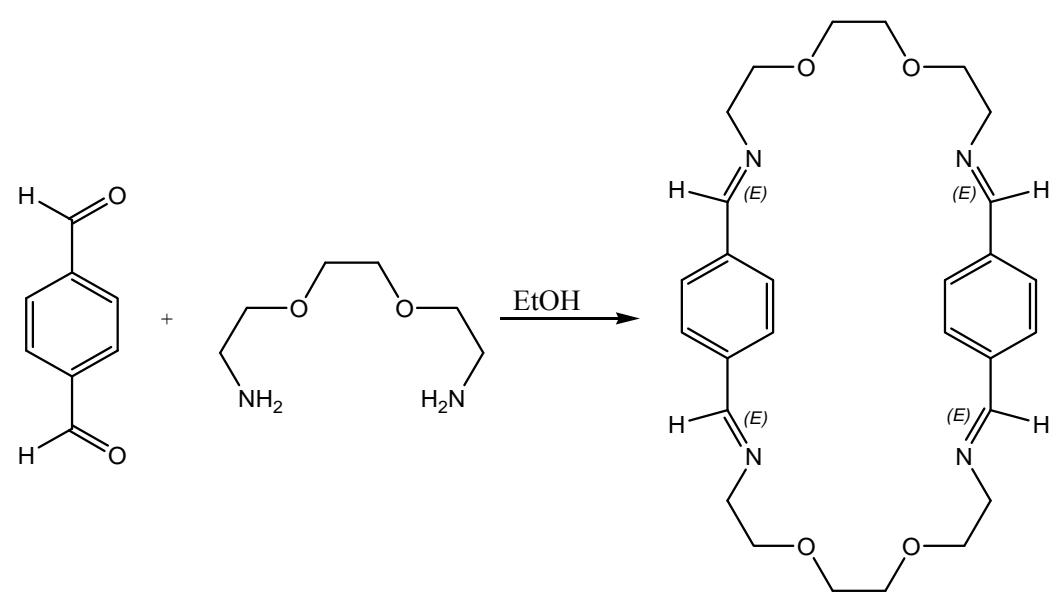

Scheme 36. Synthesis of Macrocyclic.<smiles>O=C(N/N=C/[Al])c1cc(O)c2ccoc2c1</smiles><smiles>C/C=N/NC(=O)c1cc(O)c2ccoc2c1</smiles>

Scheme 37. Novel Schiff bases of 4-Hydroxy 6-carboxyhydrazino benzofuran.<smiles>[R]c1cccc(/N=C/c2c(Cl)c3ccccc3oc2=O)c1</smiles>

Scheme 38. 4-Chloro-2-oxo-2H-chromene-3-carbaldehyde.<smiles>[R]c1ccc2c(c1)/C(=N/Nc1nc([R2])c([R3])c([R2])c1[R1])C(=O)N2</smiles>

Scheme 39. 1-(5-substituted-2-oxoindolin-3-ylidene)-4-(subbstituted-pyridin-2-yl)thiosemicarbazide.

ligand in comparison to their complexes have been determined to their complexes have been determined against bacterial strains namely Escherichia coli, Staphylococcus aureous and Pseudomonas aeruginosa [65].

Baluja et al have studied the biological activities of the following Schiff base (Scheme 41) and metal complexes [65]

Raman et al have reported the synthesis of the following Schiff ligands (Scheme 42). These authors have also studied the DNA cleavage and antimicrobial activity of the Schiff base transition metal complexes [65].

Synthesis of Schiff bases (Scheme 43) of the naptha [1,2-d] thiazol-amine and metal complexes of 2-(2'-hydroxy)benzylideneaminonaphthathiazole as potential antimicrobial agent was reported by Faizul and co-workers [65].

Rajendran and Karvembu have reported the synthesis of Schiff bases (Scheme 44) derived from 3-amino-2Hpyrano[2.3-b]quinolin-2-ones. The synthesized Schiff base compounds were screened against the fungal strain as Aspergillu nigar and Fusarium sp [65].

Raman et al have reported the synthesis of a novel 14-membered macrocyclic Schiff base (Scheme 45) derived from 3-cinnamalideneacetanalide and o-phenylenediamine which acts as a tetradentate and strongly conjugated ligand to form a cationic solid complex with $\mathrm{Cu}(\mathrm{II}) /$ $\mathrm{Ni}(\mathrm{II}) / \mathrm{Co}(\mathrm{II})$ and $/ \mathrm{Zn}(\mathrm{II})$. The ligand complexes were characterized by the usual spectral and analytical techniques. The antimicrobial tests were also recorded and gave good results in the presence of metal ions in the ligands system [65].

A series of 4-substited-emoni-methyltetrazole [1.5-a] quinoline with appropriate amine by refluxing in dioxane (Scheme 46). They have been evaluated for their antiinflammatory and antimicrobial activities [66].

Raman et al have reported the synthesis of Schiff bases (Scheme 47) of 4-aminoantipyrine neutral com- 
<smiles>Oc1ccccc1/C=N/c1cnccn1</smiles><smiles>CC(=O)Nc1ccccc1/C=N/c1cnccn1</smiles>

Scheme 40. Pyrazine-derived Schiff base ligands.<smiles>[R]c1ccc(C=Nc2ccc(S(N)(=O)=O)cc2)cc1[R]</smiles>

Scheme 41. Schiff base ligand.

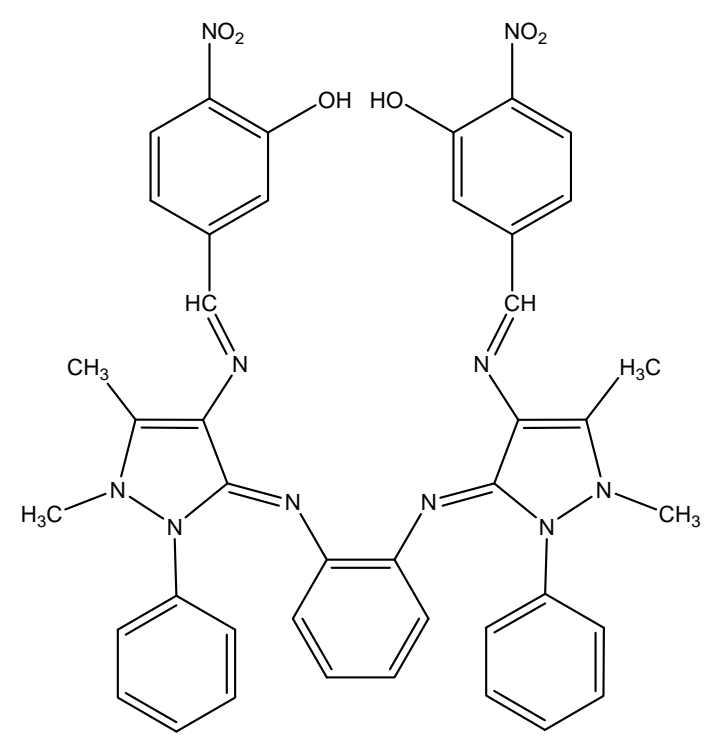

Scheme 42. Schiff base ligand.<smiles>Nc1cccc2ccccc12</smiles>

\section{$\mathrm{KSCN} / \mathrm{HC}$}<smiles>NC(=S)Nc1cccc2ccccc12</smiles>

1. $\mathrm{Br} / \mathrm{CH}_{3} \mathrm{COOH}$ 2. $\mathrm{NH}_{2} \mathrm{OH}$<smiles>[R]c1ccc(/C=N/c2nc3c(ccc4ccccc43)s2)cc1</smiles>

Scheme 43. Synthesis of Schiff bases.<smiles>[R1]c1cc2cc3cc(N=Cc4ccccc4)c(=O)oc3nc2c([R3])c1[R2]</smiles>

Scheme 44. Schiff bases derived from 3-amino2H-pyrano [2.3-b]quinolin-2-ones.

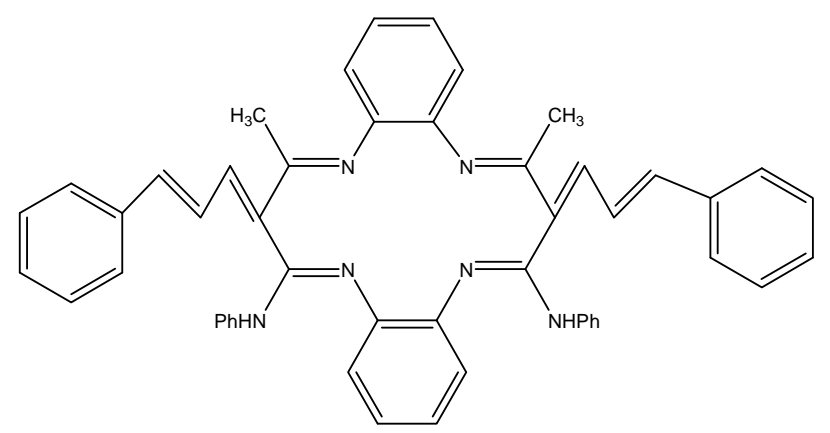

Scheme 45. Macrocyclic Schiff base derived from -cinnamalideneacetanalide and o-phenylenediamine.<smiles></smiles>

Scheme 46. Schiff bases from 4-substited-emoni-methyltetrazole[1.5-a] quinoline and appropriate amines.

plexes of $\mathrm{Cu}$ (II) from salicylidine-4-aminoantipyrine and $\mathrm{PhNH} 2 /$ substituted anilines. These authors con- firmed their structure using IR, UV-visible, ${ }^{1} \mathrm{H}-\mathrm{NMR}$ and ${ }^{13} \mathrm{C}$-NMR spectra [67]. 


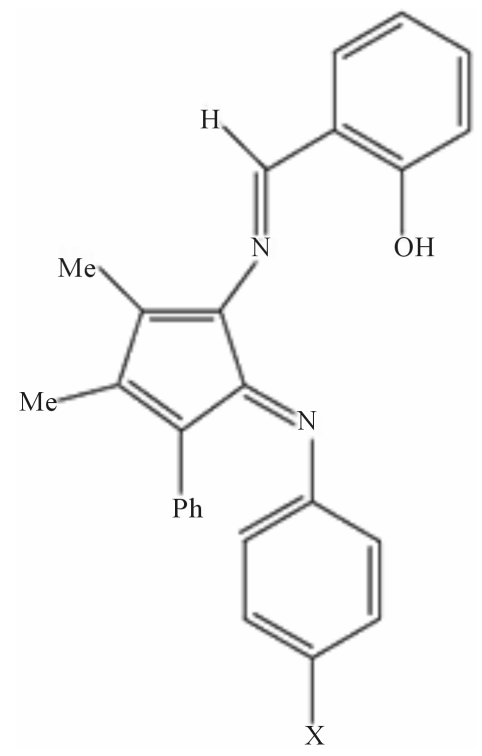

Scheme 47. Schiff bases of 4-aminoantipyrine neutral complexes of $\mathrm{Cu}(\mathrm{II})$.

\section{Conclusions}

The Chemistry of Schiff bases is a field that is being noticed. Schiff base ligands are considered privileged ligands because they are easily prepared by a simple one pot condensation of an aldehyde and primary amines.

In this review, the biological activities of Schiff base and their complexes are summarized from 1996-2012.

\section{REFERENCES}

[1] K. C. Gupta and A. K. Sutar, "Catalytic Activities of Schiff Base Transition Metal Complexes," Coordination Chemistry Reviews, Vol. 252, No. 12-14, 2008, pp. 1420-1450. http://dx.doi.org/10.1016/j.ccr.2007.09.005

[2] P. G. Cozzi, "Metal-Salen Schiff Base Complexes in Catalysis: Practical Aspects," Chemical Society Reviews, Vol. 33, No. 7, 2004, pp. 410-421. http://dx.doi.org/10.1039/b307853c

[3] B. Tu“rkkan, B. Sarıbog a and N. Sarıbog a, "Synthesis, Characterization and Antimicrobial Activity of 3,5-DiTert-Butylsalicylaldehyde-S-Methylthiosemicarbazones and Their Ni(II) Complexes," Transition Metal Chemistry, Vol. 36, No. 6, 2011, pp. 679-684. http://dx.doi.org/10.1007/s11243-011-9518-7

[4] V. L. Siji, M. R. Sudarsanakumar and S. Suma, "Synthesis, Spectroscopic Characterization, and Antimicrobial Activity of Cobalt(II) Complexes of Acetone-N(4) Phenylsemicarbazone: Crystal Structure of $\left[\mathrm{Co}(\mathrm{HL})_{2}(\mathrm{MeOH})_{2}\right]\left(\mathrm{NO}_{3}\right)_{2}$," Transition Metal Chemistry, Vol. 36, No. 4, 2011, pp. 417-424. http://dx.doi.org/10.1007/s11243-011-9485-Z

[5] C. V. Krishnamohan Sharma, "Crystal EngineeringWhere Do We Go from Here?" Crystal Growth \& Design, Vol. 2, No. 6, 2002, pp. 465-474.

http://dx.doi.org/10.1021/cg0200356

[6] I. Ahamad, R. Prasad and M. A. Quraishi, "Thermody- namic, Electrochemical and Quantum Chemical Investigation of Some Schiff Bases as Corrosion Inhibitors for Mild Steel in Hydrochloric Acid Solutions," Corrosion Science, Vol. 52, No. 3, 2010, pp. 933-942. http://dx.doi.org/10.1016/j.corsci.2009.11.016

[7] M. Antonijevic and M. Petrovic, "Copper Corrosion Inhibitors. A Review," International Journal of Electrochemical Science, Vol. 3, No. 1, 2008, pp. 1-28

[8] H. Sharghi and M. A. Nasseri, "Schiff-Base Metal(II) Complexes as New Catalysts in the Efficient, Mild and Regioselective Conversion of 1,2-Epoxyethanes to 2-Hydroxyethyl Thiocyanates with Ammonium Thiocyanate," Bulletin of the Chemical Society of Japan, Vol. 76, No. 1, 2003, pp. 137-142. http://dx.doi.org/10.1246/bcsj.76.137

[9] W. T. Gao and Z. Zheng, "Synthetic Studies on Optically Active Schiff-base Ligands Derived from Condensation of 2-Hydroxyacetophenone and Chiral Diamines," Molecules, Vol. 7, No. 7, 2002, pp. 511-516.

[10] J. Balsells, L. Mejorado, M. Phillips, F. Ortega, G. Aguirre, R. Somanathan and P. J. Walsh, "Synthesis of Chiral Sulfonamide/Schiff Base Ligands," Tetrahedron: Asymmetry, Vol. 9, No. 23, 1998, pp. 4135-4142.

[11] A. M. Isloor, B. Kalluraya and P. Shetty, "Regioselective Reaction: Synthesis, Characterization and Pharmacological Studies of Some New Mannich Bases Derived from 1,2,4-Triazoles," European Journal of Medicinal Chemistry, Vol. 44, No. 9, 2009, pp. 3784-3787. http://dx.doi.org/10.1016/j.ejmech.2009.04.038

[12] S. Krishnaraj, M. Muthukumar, P. Viswanathamurthi and S. Sivakumar, "Studies On Ruthenium(Ii) Schiff Base Complexes as Catalysts for Transfer Hydrogenation Reactions," Transition Metal Chemistry, Vol. 33, No. 5, 2008, pp. 643-648. http://dx.doi.org/10.1007/s11243-008-9091-x

[13] S. Eswaran, A. V. Adhikari and N. S. Shetty, "Synthesis and Antimicrobial Activities of Novel Quinoline Derivatives Carrying 1,2,4-Triazole Moiety," European Journal of Medicinal Chemistry, Vol. 44, No. 11, 2009, pp. 46374647. http://dx.doi.org/10.1016/j.ejmech.2009.06.031

[14] P. Przybylski, A. Huczynski, K. Pyta, B. Brzezinski and F. Bartl, "Biological Properties of Schiff Bases and Azo Derivatives of Phenols," Current Organic Chemistry, Vol. 13, No. 2, 2009, pp. 124-148.

http://dx.doi.org/10.2174/138527209787193774

[15] G. Bringmann, M. Dreyer, J. H. Faber, P. W. Dalsgaard, D. Staerk and J. W. Jaroszewski, "Ancistrotanzanine C and Related 5,1'- and 7,3'-Coupled Naphthylisoquinoline Alkaloids from Ancistrocladus tanzaniensis," Journal of $\mathrm{Na}$ tural Products, Vol. 67, No. 5, 2004, pp. 743-748. http://dx.doi.org/10.1021/np0340549

[16] A. O. deSouza, F. C. S. Galetti, C. L. Silva, B. Bicalho, M. M. Parma, S. F. Fonseca, A. J. Marsaioli, A. C. L. B. Trindade, R. P. Freitas Gil, F. S. Bezerra, M. Andrade-Neto and M. C. F. de Oliveira, "Antimycobacterial and Cytotoxicity Activity of Synthetic and Natural Compounds," Quimica Nova, Vol. 30, No. 7, 2007, pp. 1563-1566.

[17] Z. Y. Guo, R. Xing, S. Liu, Z. Zhong, X. Ji, L. Wang and P. C. Li, "Antifungal Properties of Schiff Bases of Chitosan, N-Substituted Chitosan and Quaternized Chitosan," Carbohydrate Research, Vol. 342, No. 10, 2007, pp. 1329- 
1332. http://dx.doi.org/10.1016/j.carres.2007.04.006

[18] M. S. Yadawe and S. A. Patil, "Synthesis, Characterization and Biological Studies of Cobalt (II) and Nickel(II) Complexes with New Schiff Bases," Transition Metal Chemistry, Vol. 22, No. 3, 1997, pp. 220-224. http://dx.doi.org/10.1023/A:1018400121316

[19] M. Tumer, H. Kohsal, S. Serin and M. Dig- rak, "Antimicrobial Activity Studies of Mononuclear and Binuclear Mixed-Ligand Copper (II) Complexes Derived from Schiff Base Ligands and 1,10-Phenanthroline," Transition Metal Chemistry, Vol. 24, No. 1, 1999, pp. 13-17.

[20] M. Tofazzal, H. Tarafder, M. A. Ali, N. Saravanan, W. Y. Weng, S. Kumar, N. Umar Tsafe and K. A. Crouse, "Coordination Chemistry and Biological Activity of Two Tridentate ONS and NNS Schiff Bases Derived from S-Benzyldithiocarbazate," Transition Metal Chemistry, Vol. 25, No. 3, 2000, pp. 295-298.

[21] P. Vicini, F. Zani, P. Cozzini and I. Doytchinova, "Hydrazones of 1,2-Benzisothiazole Hydrazides: Synthesis, Antimicrobial Activity and QSAR Investigations," European Journal of Medicinal Chemistry, Vol. 37, No. 7, 2002, pp. 553-564.

http://dx.doi.org/10.1016/S0223-5234(02)01378-8

[22] S. Rollas, N. Gulerman and H. Erdeniz, "Synthesis and Antimicrobial Activity of Some New Hydrazones of 4-Fluorobenzoic Acid Hydrazide and 3-Acetyl-2,5-Disubstituted-1,3,4-Oxadiazolines," II Farmaco, Vol. 57, No. 2, 2002, pp. 171-174.

[23] I. Yilmaz and A. Cukurovali, "Synthesis, Characterization and Antimicrobial Activity of the Schiff Bases Derived from 2,4-Disubstituted Thiazoles and 3-Meth-oxysalicylaldehyde, and Their Cobalt(II), Copper(II), Nickel(II) and Zinc(II) Complexes," Transition Metal Chemistry, Vol. 28, No. 4, 2003, pp. 399-404.

[24] N. Ramam, A. Kulandaisamy, C. Thangaraja and K. Jeyasubramanian, "Redox and Antimicrobial Studies of Transition Metal (II) Tetradentate Schiff Base Complexes," Transition Metal Chemistry, Vol. 28, No. 1, 2003, pp. 2936.

[25] T. D. Thangadurai and S. K. Ihm, "Antimicrobial Activities against Methicillin-Resistant Staphylococcus aureus from macroalgae," Journal of Industrial and Engineering Chemistry, Vol. 14, No. 5, 2008, pp. 568-572. http://dx.doi.org/10.1016/j.jiec.2008.04.004

[26] Raman and S. Johnson Raja, "DNA Cleavage, Structural Elucidation and Anti-Microbial Studies of Three Novel Mixed Ligand Schiff Base Complexes of Copper(II)," Journal of the Serbian Chemical Society, Vol. 72, No. 10, 2007, pp. 983-992.

[27] R. Maruvada, S. C. Pal and G. B. Nair, "Effects of Polymyxin B on the Outer Membranes of Aeromonas Species," Journal of Microbiological Methods, Vol. 20, No. 2, 1994, pp. 115-124. http://dx.doi.org/10.1016/0167-7012(94)90014-0

[28] T. J. Franklin and G. A. Snow, "Penetrating the Defences," In: Biochemistry of Antimcrobial Action, 2nd Edition, Chapman, Hall, London, 1971, pp. 1-16.

[29] G. Turan-Zitouni, Z. A. Kaplancıklı, M. T. Yıldı, P. Chevallet and D. Kaya, "Synthesis and Antimicrobial Activity of
4-phenyl/cyclohexyl-5-(1-phenoxyethyl)-3-[N-(2-thiazolyl) acetamido]-thio-4H-1,24-triazole Derivatives," European Journal of Medicinal Chemistry, Vol. 40, No. 6, 2005, pp. 607-613. http://dx.doi.org/10.1016/j.ejmech.2005.01.007

[30] W. Rehman, M. K. Baloch, B. Muhammad, A. Badshah and K. M. Khan, "Characteristic Spectral Studies and in Vitro Antifungal Activity of Some Schiff Bases and Their Organotin (VI) Complexes," Chinese Science Bulletin, Vol. 49, No. 2, 2004, pp. 119-122.

[31] L. Sakiyan, E. Logoglu, S. Arslan, N. Sari and N. Sakiyan, "Antimicrobial Activities of N-(2-Hydroxy-1-Naphthalidene)-Amino Acid(Glycine, Alanine, Phenylalanine, Histidine, Tryptophane) Schiff Bases and Their Manganese(III) Complexes," Biometals, Vol. 17, No. 2, 2004, pp. 115-120.

[32] A. Vazzana, E. Terranova, F. Mattioli and F. Sparatore, "Aromatic Schiff Bases and 2,3-Disubstituted-1,3-Thiazolidin-4-One Derivatives as Antiinflammatory Agents," ARKIVOC, Vol. 2004, No. 5, 2004, pp. 364-374.

[33] E. İspir, M. Kurtoğlu, F. Purtaş and S. Serin, "Synthesis and Antimicrobial Activity of New Schiff Bases Having the $-\mathrm{SiOR}$ Group $(R=\mathrm{CH} 3$ or $\mathrm{CH} 2 \mathrm{CH} 3)$, and Their Transition Metal Complexes," Transition Metal Chemistry, Vol. 30, No. 8, 2005, pp. 1042-1047. http://dx.doi.org/10.1007/s11243-005-6311-5

[34] S. K. Sengupta, O. P. Pandey, B. K. Srivastava and V. K. Sharma, "Trends in Structural Mechanics: Theory, Practice," Transition Metal Chemistry, Vol. 23, 1998, p. 349.

[35] M. Kurtoglu, E. Ispir, N. Kurtolu, S. Toroglu, S. Serin, R. N. Srivastava and A. Bagga, "Pediatric Nephrology," In: Transition Metal Chemistry, 2005.

[36] N. Raman, J. Joseph, A. S. Kumara and C. Pothiraj, "Antifungal Activities of Biorelevant Complexes of Copper(II) with Biosensitive Macrocyclic Ligands," Mycobiology, Vol. 34, No. 4, 2006, pp. 214-218.

[37] H. M. Parekh, S. R. Mehta and M. N. Patel, "Synthesis, Structural Characterization, and Antifungal Activity of Schiff Bases and Their Transition Metal Mixed Ligand Complexes," Russian Journal of Inorganic Chemistry, Vol. 51, No. 1, 2006, pp. 67-72.

[38] M. Wujec, U. Kosikowska, P. Paneth and A. Malm, "Reaction of Hydrazide of (tetrazol-5-yl)Acetic Acid with Isothiocyanates and Antimicrobial Investigations of NewlyObtained Compounds," Heterocycles, Vol. 71, No. 12, 2007, pp. 2617-2626. http://dx.doi.org/10.3987/COM-07-11129

[39] D. Yong, M. A. Toleman, C. G. Giske, H. S. Cho, K. Sundman, K. Lee and T. Walsh, "Characterization of a New Metallo- $\beta$-Lactamase Gene, blaNDM-1, and a Novel Erythromycin Esterase Gene Carried on a Unique Genetic Structure in Klebsiella pneumoniae Sequence Type 14 from India," Antimicrobial Agents and Chemotherapy, Vol. 53, No. 12, 2009, pp. 5046-5054. http://dx.doi.org/10.1128/AAC.00774-09

[40] H. Bayrak, A. Demirbas, N. Demirbas and S. A. Karaoglu, "Synthesis of Some New 1,2,4-Triazoles Starting from Isonicotinic Acid Hydrazide and Evaluation of Their Antimicrobial Activities," European Journal of Medicinal Chemistry, Vol. 44, No. 11, 2009, pp. 4362-4366. http://dx.doi.org/10.1016/j.ejmech.2009.05.022

[41] M. Shakir, Y. Azim, H. T. N. Chishti and S. Parveen, "Syn- 
thesis, Characterization of Complexes of $\mathrm{Co}(\mathrm{II}), \mathrm{Ni}(\mathrm{II})$, $\mathrm{Cu}(\mathrm{II})$ and $\mathrm{Zn}$ (II) with 12-Membered Schiff Base Tetraazamacrocyclic Ligand and the Study of Their Antimicrobial and Reducing Power," Spectrochimica Acta Part A: Molecular and Biomolecular Spectroscopy, Vol. 65, No. 2, 2006, pp. 490-496. http://dx.doi.org/10.1016/j.saa.2005.11.029

[42] L. Shi, H. M. Ge, S. H. Tan, H. Q. Li, Y. C. Song, H. L. Zhu and R. X. Tan, "Synthesis and Antimicrobial Activities of Schiff Bases Derived from 5-Chloro-Salicylaldehyde," European Journal of Medicinal Chemistry, Vol. 42, No. 4, 2007, pp. 558-564. http://dx.doi.org/10.1016/j.ejmech.2006.11.010

[43] H. Mukundan, A. S. Anderson, W. K. Grace, K. M. Grace, N. Hartman, J. S. Martinez and B. I. Swanson, "WaveguideBased Biosensors for Pathogen Detection," Sensors, Vol. 9, No. 7, 2009, pp. 5783-5809. http://dx.doi.org/10.3390/s90705783

[44] B. Sammanta, J. Chakraborty, C. R. Choudhury, S. K. Dey, D. K. Dey, S. R. Batten, P. Jensen, G. P. A. Yap and S. Mitra, "New $\mathrm{Cu}$ (II) Complexes with Polydentate Chelating Schiff Base Ligands: Synthesis, Structures, Characterisations and Biochemical Activity Studies," Structural Chemistry, Vol. 18, No. 1, 2007, pp. 33-41. http://dx.doi.org/10.1007/s11224-006-9115-0

[45] D. P. Singh, R. Kumar and J. Singh, "Synthesis and Spectroscopic Studies of Biologically Active Compounds Derived from Oxalyldihydrazide and Benzil, and Their $\mathrm{Cr}(\mathrm{III}), \mathrm{Fe}(\mathrm{III})$ and $\mathrm{Mn}(\mathrm{III})$ Complexes," European Journal of Medicinal Chemistry, Vol. 44, No. 4, 2009, pp. 1731-1736.

[46] T. Farkas, M. Antal, L. Sámi, P. Germán, S. Kecskemé, G. Kardos, S. Belák and I. Kiss, "Rapid and Simultaneous Detection of Avian Influenza and Newcastle Disease Viruses by Duplex Polymerase Chain Reaction Assay," Zoonoses and Public Health, Vol. 54, No. 1, 2007, pp. 38-43. http://dx.doi.org/10.1111/j.1863-2378.2007.01005.x

[47] V. P. Singh, A. Katiyar and S. Singh, "Synthesis, Characterization of Some Transition Metal(II) Complexes of Acetone $p$-Amino Acetophenone Salicyloyl Hydrazone and their Anti Microbial Activity," Biometals, Vol. 21, No. 4, 2008, pp. 491-501. http://dx.doi.org/10.1007/s10534-008-9136-9

[48] W. Rehman, F. Saman and I. Ahmad, "Synthesis, Characterization, and Biological Study of Some Biologically Potent Schiff Base Transition Metal Complexes," Russian Journal of Coordination Chemistry, Vol. 34, No. 9, 2008, pp. 678-682.

http://dx.doi.org/10.1134/S107032840809008X

[49] H. Khanmohammadi, M. H. Abnosi, A. Hosseinzadeh and M. Erfantalab, "Synthesis, Biological and Computational Study of New Schiff Base Hydrazones Bearing 3-(4-Pyridine)-5-Mercapto-1,2,4-Triazole Moiety," Spectrochimica Acta Part A: Molecular and Biomolecular Spectroscopy, Vol. 71, No. 4, 2008, pp. 1474-1480.

http://dx.doi.org/10.1016/j.saa.2008.05.003

[50] C. Yuan, L. Lu, X. Gao, Y. Wu, M. Guo, Y. Li, X. Fu and M. Zhu, "Ternary Oxovanadium(IV) Complexes of ONODonor Schiff Base and Polypyridyl Derivatives as Protein Tyrosine Phosphatase Inhibitors: Synthesis, Characteriza- tion, and Biological Activities," Journal of Biological Inorganic Chemistry, Vol. 14 , No. 6, 2009, pp. 841-851. http://dx.doi.org/10.1007/s00775-009-0496-6

[51] V. B. Badwaik, R. D. Deshmukh and A. S. Aswar, "Synthesis, Structural, and Biological Studies of Some Bivalent Metal Ion Complexes with the Tridentate Schiff Base Ligand," Russian Journal of Coordination Chemsitry, Vol. 35, No. 4, 2009, pp. 247-252.

[52] L. A. Saghatforoush, A. Aminkhani and F. Chalabian, "Iron(III) Schiff Base Complexes with Asymmetric Tetradentate Ligands: Synthesis, Spectroscopy, and Antimicrobial Properties," Transition Metal Chemistry, Vol. 34 , No. 8, 2009, pp. 899-904.

http://dx.doi.org/10.1007/s11243-009-9279-8

[53] D. P Singh, K. Kumar and C. Sharma, "Antimicrobial Active Macrocyclic Complexes of $\mathrm{Cr}(\mathrm{III}), \mathrm{Mn}(\mathrm{III})$ and Fe(III) with Their Spectroscopic Approach," European Journal of Medicinal Chemistry, Vol. 44, No. 8, 2009, pp. 3299-3304. http://dx.doi.org/10.1016/j.ejmech.2009.02.029

[54] K. Shanker, R. Rohini, V. Ravinder, P. M. Reddy and Y. P. Ho, "Ru(II) Complexes of $\mathrm{N}_{4}$ and $\mathrm{N}_{2} \mathrm{O}_{2}$ Macrocyclic Schiff Base Ligands: Their Antibacterial and Antifungal Studies," Spectrochimica Acta Part A: Molecular and Biomolecular Spectroscopy, Vol. 73, No. 1, 2009, pp. 205-211. http://dx.doi.org/10.1016/j.saa.2009.01.021

[55] I. H. Pandya and M. K. Shah, "Synthesis and Antimicrobial Properties of Transition Metal Complexes of Novel Schiff Base Ligand Derived from 5-Bromosalicyldehyde," Journal of Indian Council of Chemists, Vol. 26, No. 2, 2009, pp. 109-112.

[56] H. Bayrak, A. Demirbas, S. A. Karaoglu and N. Demirbas, "Synthesis of Some New 1,2,4-Triazoles, Their Mannich and Schiff Bases and Evaluation of Their Antimicrobial Activities," European Journal of Medicinal Chemistry, Vol. 44, No. 3, 2009, pp. 1057-1066.

http://dx.doi.org/10.1016/j.ejmech.2008.06.019

[57] R. V. Singh, P. Chaudhary, S. Chauhan and M. Swami, "Microwave-Assisted Synthesis, Characterization and Biological Activities of Organotin (IV) Complexes with Some Thio Schiff Bases," Spectrochimica Acta Part A: Molecular and Biomolecular Spectroscopy, Vol. 72, No. 2, 2009, pp. 260-268.

[58] B. I. Slavica, K. Sandra, S. Dragiša, B. V. Vlada and C. Gojgić, "The Impact of Schiff Bases on Antibiotic Production by Streptomyces hygroscopicus," Medicinal Chemistry Research, Vol. 19, No. 7, 2010, pp. 690-697.

[59] Z. Yang and L. W. Hui, "Syntheses, Crystal Structures and Antibacterial Activities of Azido-Bridged Cobalt (III) Complexes with Schiff Bases," Transition Metal Chemistry, Vol. 35, No. 6, 2010, pp. 745-749.

[60] A. K. Singh, O. P. Pandey and S. K. Sengupta, "Synthesis, Spectral Characterization and Biological Activity of Zinc(II) Complexes with 3-Substituted Phenyl-4-Amino-5-Hydrazino-1, 2, 4-Triazole Schiff Bases," Spectrochimica Acta Part A: Molecular and Biomolecular Spectroscopy, Vol. 85 , No. 1, 2012, pp. 1-6.

[61] A. B. Gunduzalp and H. F. Ozbay, "The Synthesis, Characterization and Antibacterial Activities of Dinuclear 
$\mathrm{Ni}(\mathrm{II}), \mathrm{Cu}(\mathrm{II})$ and $\mathrm{Fe}(\mathrm{III})$ Schiff Base Complexes1," Russian Journal of Inorganic Chemistry, Vol. 57, No. 2, 2012, pp. 257-260.

[62] T. Plech, M. Wujec, M. Majewska, U. Kosikowska and A. Malm, "Microbiologically Active Mannich Bases Derived from 1,2,4-Triazoles. The Effect of C-5 Substituent on Antibacterial Activity," Medicinal Chemistry Research, Vol. 22, No. 5, 2013, pp. 2531-2537.

[63] A. M. Hassan, A. M. Nassar, Y. Z. Hussien and A. N. Elkmash, "Synthesis, Characterization and Biological Evaluation of Fe (III), Co (II), Ni(II), Cu(II), and Zn(II) Complexes with Tetradentate Schiff Base Ligand Derived from Protocatechualdehyde with 2-Aminophenol," Applied Biochemistry and Biotechnology, Vol. 167, No. 3, 2012, pp. 581-594.

[64] M. Kalanithi, M. Rajarajan, P. Tharmaraj and C. D. Sheela, "Redox and Antimicrobial Studies of Transition Metal(II) Tetradentate Schiff Base Complexes," Spectrochimica Acta Part A: Molecular and Biomolecular Spec- troscopy, Vol. 87 , 2012, pp. 155-162.

[65] S. Arulmurugan, H. P. Kavitha1 and B. R. Venkatraman, "Biolgical Activties of Shiff Base and Its Complexes: A Review," Rasayan Journal of Chemistry, Vol. 3, No. 3, 2010, pp. 385-410.

[66] N. Raman and C. Thangaraja, "Synthesis and Structural Characterization of a Fully Conjugated Macrocyclic Tetraaza(14)-Membered Schiff Base and Its Bivalent Metal Complexes," Transition Metal Chemistry, Vol. 30, No. 3, 2005, pp. 317-322. http://dx.doi.org/10.1007/s11243-004-5831-8

[67] N. Raman, A. Kulandaisamy, C. Thangaraja, P. Manisankar, S. Viswanathan and C. Vedhi, "Synthesis, Structural Characterisation and Electrochemical and Antibacterial Studies of Schiff Base Copper Complexes," Transition metal Chemistry, Vol. 29, No. 2, 2004, pp. 129-135. 